\title{
NOTES ON BLACKFLIES (DIPTERA: SIMULIIDAE) FROM SULAWESI, INDONESIA
}

\author{
HIROYUKI TAKAOKA ${ }^{1}$ AND D. M. ROBERTS ${ }^{2}$ \\ Received June 13 1988/Accepted August 161988
}

\begin{abstract}
A total of nine taxa of Simuliidae, including six new species, were collected from northern Sulawesi, Indonesia. All belong to the genus Simulium Latreille, and are assigned to the subgenera Nevermannia Enderlein $\{S .(N$.$) aureohirtum Brunetti and$ another unnamed species\}, Morops Enderlein (1 new species), Gomphostilbia Enderlein (3 new species and another unnamed species) and Simulium Latreille s. str. (2 new species). Descriptions of all the new species are provided, with keys for their separation. Notes on their taxonomic relationships and the ecology of the immature stages are given.
\end{abstract}

\section{INTRODUCTION}

The simuliid fauna of Indonesia has not been studied since Edwards (1934) described 11 new species from Sumatra, Java and Bali, making a total of 18 species for this archipelago, although those of neighbouring areas in the Oriental Region have recently been studied (e. g. Sabah by Smart and Clifford, 1969; Philippines by Takaoka, 1983)

The present paper reports the results of blackfly collections made for the first time in Sulawesi during 1985 as part of the Royal Entomological Society's "Project Wallace Expedition". The majority of blackfly specimens examined were collected by the junior author; in addition some other samples which were collected by other investigators were loaned for study from British Museum (Natural History). In total, nine taxa of simuliids are treated, consisting of one known species, two unnamed species and six new species. The new species are described and keys are provided for all stages. Notes on their taxonomic affinities with related species are presented, as well as notes on their ecology.

\section{MATERIALS AND METHODS}

1. Study Area

Collections were made in two areas of northern Sulawesi during August and September 1985:

a) The Toraut/Tumpah river system in the Dumoga-Bone Reserve $\left(0^{\circ} 34^{\prime} \mathrm{N} ; 123^{\circ} 54^{\prime} \mathrm{E}\right)$. The River Tumpah is a wide $(20-30 \mathrm{~m})$ but shallow river flowing on a rock bed with little trailing

1 Division of Medical Zoology, Medical College of Oita, Hazama, Oita 879-56, Japan

2 Department of Zoology, University of Jos, P.M.B. 2084, Jos, Nigeria (Present address: Westerley House, Brook Street, Shipton Gorge, Dorset DT6 4NA, U.K.). 
vegetation through primary forest. It descends steeply, and was sampled at different altitudes from 550 to $200 \mathrm{~m}$, where it joined the R. Toraut, a similar sized river. The R. Toraut then flows through the farmland areas of the Dumoga Valley, where small tributaries flowing off the surrounding hills were sampled, as well as the irrigation channels on the valley floor.

b ) Small streams flowing into Lake Mooat $\left(0^{\circ} 45^{\prime} \mathrm{N} ; 124^{\circ} 27^{\prime} \mathrm{E}\right)$ at an altitude of $1,100 \mathrm{~m}$. Most of the streams sampled flowed through coffee plantations, but two were sampled in the forest. All were small (maximum of $2 \mathrm{~m}$ wide) and fairly slow flowing.

\section{Taxonomic Study}

The majority of the taxonomic specimens used were collected as larvae and pupae, from which adult males and females were reared. The specimens were preserved in $80 \%$ ethanol. The laboratory procedures used in this work were almost the same as those described by Takaoka (1983). The measurement of the hind basitarsus and tarsal claw tooth follows that of Davies and Györkös (1987). The morphological features and terms used follow those of Crosskey (1969)

\section{Ecological Study}

At each collecting site, the river width, depth and altitude were noted. In order to investigate the velocity preferences of each species, artificial substrates were suspended in six different velocity ranges for three sites in the $\mathrm{R}$. Tumpah and one in the R. Toraut, using an experimental design described in Roberts and Okafor (1987). However, very few larvae colonized either polythene stripes or strings, so the experiment was abandoned. Instead, as far as possible, all the pupae within the sampling site were collected up. Where each pupa was found, the substrate type was noted and the velocity measured using a $2 \mathrm{~cm}$ wide ruler calibrated against a velocity meter (see Roberts and Okafor, 1987), which allows spot measurements of velocity. This method involves some error in underestimating high velocity preferences, particularly in small streams, but allows comparison of velocity preferences of different species in the same river.

\section{Disposition OF TyPE SPECIMENS}

All holotype, allotype and some of paratype specimens are in due course deposited in British Museum (Natural History), London, and some paratypes are also deposited in Bernice P. Bishop Museum, Honolulu, Hawaii.

\section{SYSTEMATICS}

The present study follows the classification of Crosskey (1981), in which subgenus Eusimulium Roubaud within the genus Simulium Latreille s. 1. is divided into two subgenera: Eusimulium, which is restricted for the aureum group, and Nevermannia Enderlein, which is used for the rest of Eusimulium in old sense. Accordingly, nine taxa collected from Sulawesi are classified as follows: 
Genus Simulium Latreille s. 1.

Subgenus Nevermannia Enderlein

ruficorne group

S. aureohirtum Brunetti, 1911

feuerborni group

S. sp. A

Subgenus Morops Enderlein

$S$. disneyi sp. nov.

Subgenus Gomphostilbia Enderlein

ceylonicum group

S. sulawesiense sp. nov.

S. torautense sp. nov.

$S$. rosemaryae sp. nov.

S. np. B

Subgenus Simulium Latreille s. str.

melanopus group

S. dumogaense sp. nov.

S. tumpaense sp. nov.

\section{Keys to the Species of Simuliddae in Sulawesi}

\section{Adult females}

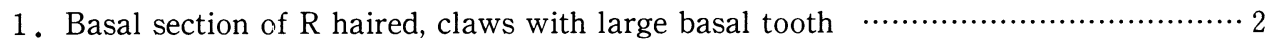

Basal section of $\mathrm{R}$ bare, claws simple or with small basal tooth $\cdots \cdots \cdots \cdots \cdots \cdots \cdots \cdots \cdots \cdots \cdots \cdots \cdots \cdots \cdots$

2. Katepisternum bare

S. (N.) aureohirtum

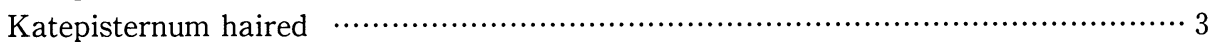

3. Pleural membrane haired …................................................... (N.) disneyi

Pleural membrane bare ….................................................................. 4

4. Mid basitarsus entirely dark brown; mandible without teeth on outer margin

S. (G.) sulawesiense

Mid basitarsus whitish yellow on basal $1 / 3$ or $1 / 2$; mandible with teeth on outer margin

.. 5

5. Mid and hind tibiae brown except basal extreme pale white

S. (G.) torautense

Mid and hind tibiae white on basal $1 / 2$ and brown on distal $1 / 2 \cdots \cdots . .$. . (G.) rosemaryae

6. Claws with small basal tooth ……........................................ (S.) dumogaense

Claws without tooth …...................................................... (S.) tumpaense

\section{Adult males}

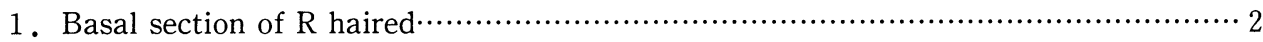

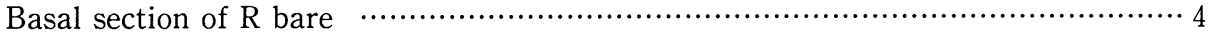

2. Katepisternum bare ……................................................. (N.) aureohirtum

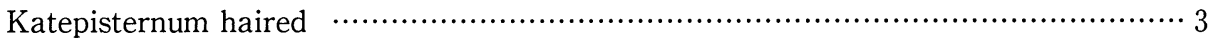

3. Hind basitarsus slender, parallel-sided (Fig. 11b) …....................... (G.) torautense

Hind basitarsus enlarged, wedge-shaped (Fig. 12b) …................... $(G$.) rosemaryae

4. Hind basitarsus white on basal $1 / 4$ and brownish black on the rest (Fig. 13b); style with non-serrated, pointed basal protuberance (Fig. 26d) …............ (S.) dumogaense 
Hind basitarsus white on basal $1 / 2$, or a little more and brownish black on the rest (Fig. $14 \mathrm{~b})$; style with serrated basal protuberance (Fig. 27d) S. (S.) tumpaense

\section{Pupae}

1. Gill with 6 filaments

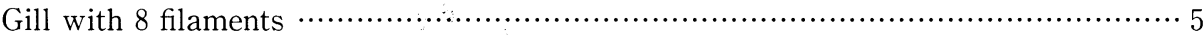

2. Last abdominal segment with terminal hooks; cocoon wall pocket-shaped, without distinct high anteroventral neck …................................................... 3

Last abdominal segment without terminal hooks; cocoon shoe-shaped, with distinct high anteroventral neck

3 . Tergum 6 without spine-combs; last abdominal segment lacks grapnel-like hooklets $\cdots$ S. ( N.) aureohirtum

Tergum 6 with spine-combs; last abdominal segment with a few grapnel-like hooklets S. (G.) rosemaryae

4. Trichomes on head and thoracic integument branched S. (S.) dumogaense Trichomes on head and thoracic integument simple S. (S.) tumpaense

5. Stalk of ventral pair of filaments short and dorsal and middle triplets not arising on the same vertical plane (Fig. 28b); cocoon with anterodorsal projection (Fig. 33a) …...

S. (G.) torautense

Stalk of ventral pair of filaments long and dorsal and middle triplets arising nearly on the same vertical plane (Fig. 30c); cocoon without anterodorsal projection

\section{Larvae}

1. Ventral papillae present

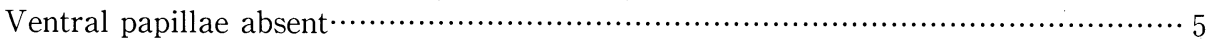

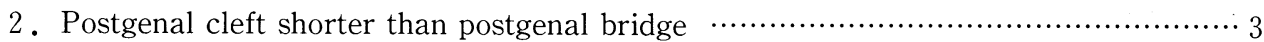

Postgenal cleft much longer than postgenal bridge …........................................ 4

3 . Postgenal cleft a little shorter than $1 / 2$ of postgenal bridge; abdomen with distinct dorsal colored pattern …...................................... $(N$.$) sp. A (feuerborni-group)$

Postgenal cleft a little shorter than postgenal bridge; abdomen without any dorsal colored pattern …...................................................... (..$)$ aureohirtum

4. Cephalic apotome pale with faint positive head spots (Fig. 41a); posterior abdominal segments covered dorsally with branched minute spines........... $(G$.) rosemaryae

Cephalic apotome largely darkened centrally and posteriorly (Fig. 40a); abdominal segments covered dorsally with simple minute spines ……….... $(G$.) torautense

5. Postgenal cleft subtriangular, gradually narrowed anteriorly (Fig. 42b)

S. (S.) dumogaense

Postgenal cleft rounded, widest at basal $1 / 3$ (Fig. 43b) ……............ (S.) tumpaense

\section{Species Accounts}

Subgenus Nevermannia Enderlein

Simuliun (Nevermannia) aureohirtum Brunetti

Simulium aureohirtum Brunetti 1911: 283-288; Edwards, 1934: 134-137. 
Simulium (Nevermannia) aureohirtum: Ogata, 1956: 61-62; Ogata, 1966: 129.

Simulium (Eusimulium) aureohirtum: Puri, 1933: 1-7; Ogata and Sasa, 1954: 325; Ogata, Sasa and Suzuki, 1956: 73; Crosskey, 1973: 423; Takaoka, 1976: 170-171; Takaoka, 1979: 382-384; Takaoka and Suzuki, 1984: 11-12.

Eusimulium aureohirtum: Orii, Uemoto and Onishi, 1969: 1-13

Simulium (Eusimulium) tuaranense Smart and Clifford, 1969: 40-43. Syn. by Crosskey 1973. Simulium (Eusimulium) philippinense Delfinado 1962: 47-62. Syn. by Takaoka 1983.

Simulium $(N$.$) aureohirtum was originally described from Umling, Assam, India$ (Brunetti, 1911). The female, male, pupa and larva of this species were redescribed by Puri (1933) and Takaoka (1979). The morphological characters of the Sulawesi specimens conform at all stages to the redescription given by Takaoka (1979), which was based on Taiwanese specimens, except that upstanding hairs on the male scutellum are not brown but pale, and the upper eye of the male is composed of medium-sized facets in 22 or 23 horizontal rows in place of 18 rows. With regard to the latter character, a reexamination showed that the Taiwanese male specimens practically have the same rows of medium facets in the upper eye as do the Sulawesi specimens. In redescription, a few short rows of facets near the under margin unfortunately escaped the counting.

This species belongs to the ruficorne group and is widely distributed in the Oriental Region and parts of the Palaearctic Region. This is a first record for this species from Sulawesi.

Material examined: 4 females, 12 males, 24 pupae and 14 mature larvae, SULAWESI: Dumoga-Bone Reserve, tributaries of R. Toraut, D. M. Roberts, Sept. 1985; 1 female (BMNH), collected by light trap, Dumoga-Bone Reserve, Project Wallace Base Camp area, R. H. L. Disney, Sept. 1985.

Ecological notes: The Sulawesi population of this species may be autogenous, as already reported elsewhere by Takaoka and Noda (1979). It was found in some small streams 20 $\mathrm{cm}^{-2} \mathrm{~m}$ wide flowing into the R. Toraut in the Dumoga Valley at an altitude of $200 \mathrm{~m}$, where it was associated with $S$. $(G$.) torautense, $S$. (S.) tumpaense and $S .(G)$. rosemaryae. It was also found by itself in a stream flowing into Lake Mooat at an altitude of 1,100 m. Immature stages were normally attached to dead leaves or trailing grass.

Distribution: India, Sri Lanka, Thailand, China (Yunnan), Sumatra, Java, Borneo, Sulawesi (new record), Philippines, Taiwan, Japan.

\section{Simulium (Nevermannia) sp. A}

This species seems to be assignable to the feuerborni group, as defined by Datta (1973), by the gill histoblast with six filaments, the small postgenal cleft (a little less than $1 / 2$ as long as postgenal bridge), and the presence of the characteristic dorsal colored pattern on the larval abdomen. The morphological characters of the larva mostly agree with those of $S$. (N.) feuerborni reported from Java and Bali (Edwards, 1934). The dorsal colored pattern on the larval abdomen, which seems to be species-characteristic in this species group, is very similar to each other. The adult and pupal specimens are needed for final identification.

This represents the first distribution record of the feuerborni group in Sulawesi.

Material examined: 2 early mature larvae, 4 immature larvae, SULAWESI: Dumoga-Bone Reserve, tributary of R. Tumpah, D. M. Roberts, Sept. 1985.

Ecological notes: Unknown. 
Distribution: Sulawesi.

\section{Subgenus Morops Enderlein \\ Simulium (Morops) disneyi sp. nov.}

Female. Body length $3.2 \mathrm{~mm}$. Wing length $2.0 \mathrm{~mm}$. Head. Nearly as wide as thorax. Frons brownish black, semishiny, whitish grey pruinose, and covered densely with whitish yellow appressed pubescence; frontal ratio 1.6:1.0:3.0; frons-head ratio 1.0:6.4. Clypeus brownish black, semishiny, whitish grey pruinose, and densely covered with whitish yellow appressed pubescence, and sparsely with dark hairs. Antenna composed of $2+9$ segments, brown except scape, pedicel and base of 1st flagellar segment yellow. Maxillary palp with 5 segments, proportion of $3 \mathrm{rd}, 4$ th and 5th segments in length 1.0:1.06:2.6; 3rd segment normal in shape and size, and with small sensory vesicle which is about $1.6 \times$ as long as wide, and about $1 / 4 \times$ as long as 3rd segment (Fig. 1). Maxilla with 12 inner teeth and 13 outer teeth. Mandible serrulated only on inner side, with 24 teeth, and devoid of any distinct teeth on outer side. Cibarium without denticles. Thorax. Scutum faintly whitish grey pruinose on brownish black background, with 3 faintly discernible longitudinal black vittae (1 medially and 2 submedially); scutum densely covered with whitish yellow appressed pubescence. Scutellum dark brown, faintly whitish grey pruinose, and with long and short hairs. Postscutellum brownish black, faintly-whitish grey pruinose, and bare. Pleural membrane with 4 pale hairs on upper
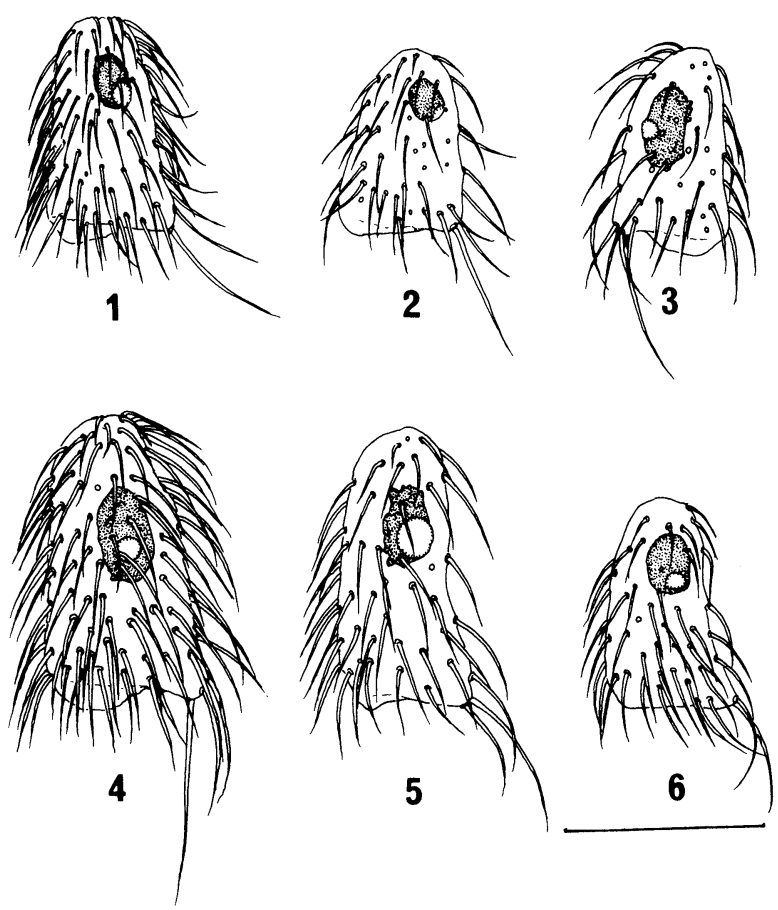

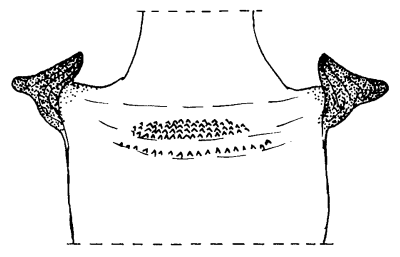

7

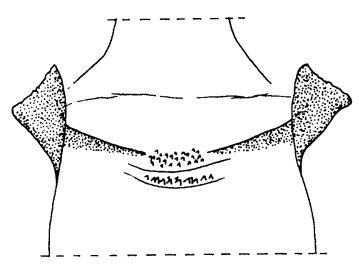

8 F

Figs. 1-8 Third segments of maxillary palps of female adults showing sensory vesicle (Figs. 16) and cibaria (Figs. 7 and 8): 1, S. disneyi; 2, S. sulawasiense; 3, S. torautense; $4, S$. rosemaryae; 5 and $7, S$. dumogaense; 6 and $8, S$. tumpaense. Scale $0.1 \mathrm{~mm}$. 
region. Katepisternum longer than deep, and with numerous whitish yellow hairs as well as numerous dark hairs. Legs. Fore coxa whitish yellow, mid coxa dark brown and hind one brown. Fore and mid trochanters brown, and hind one whitish yellow. All femora brown with distal $1 / 3$ of hind femur dark brown. Fore tibia brown with median portion largely pale brown on outer surface. Mid tibia brown except extreme base whitish yellow, and hind tibia whitish yellow on basal $1 / 5$, and brown on the rest (somewhat darkened distally with distal $1 / 3$ dark brown) and with dark trace of subbasal ring laterally; hind tibia covered with white appressed pubescence on posterior and lateral surfaces of basal $3 / 5$ of their shaft. Fore tarsi brownish black; basitarsus cylindrical, $5.5 \times$ as long as its greatest width. Mid tarsi dark brown to brownish black. Hing tarsi brownish black except basal $2 / 3$ of basitarsus (though base of basitarsus brown) and basal 1/2 of 2nd segment white; basitarsus (Fig. 9a) narrow, nearly parallel-sided. Calcipala (Fig. 9a) well developed, about $7 / 10 \times$ as wide as width of distal portion of basitarsus, and its tip reaching distal $1 / 3$ of 2 nd tarsal segment. Pedisulcus well developed. Claw (Fig. 9c) with basal tooth, which is $1 / 2 \times$ length of claw. Wing. C with spinules and hairs. Sc setate throughout its length on undersurface. Basal section of $\mathrm{R}$ haired. $\mathrm{R}_{1}$ with spinules and hairs. $\mathrm{R}_{2}$ with dark hairs. Basal cell absent. Haltere white, with petiole dark. Abdomen. Basal scale dark brown with white hair fringe. Dorsal surface of abdominal segments dark grey with tergites dark brown to brownish black, and sparsely covered with dark hairs; tergites of segments 6-8 shiny. Genitalia. Sternite 8 bare medially and with about 22 stout hairs laterally on each side. Anterior gonapophysis simple, membraneous, and with numerous microsetae; inner margin moderately sclerotized; posteromedial corner largely rounded (Fig. 18a). Genital fork (Fig. 18a) reversed-Y shaped, with well sclerotized stem; arms diverged laterally, and with well sclerotized distal ridge which is somewhat produced anteriorly. Paraproct (Figs. 18a, c) simple, with about 30 stout hairs on

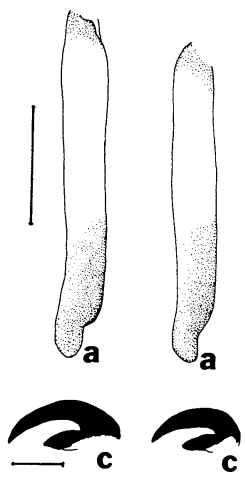

9 10
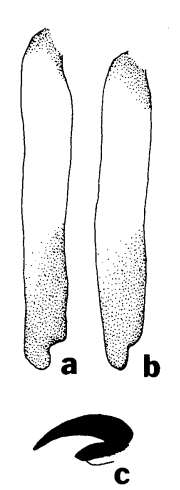

11

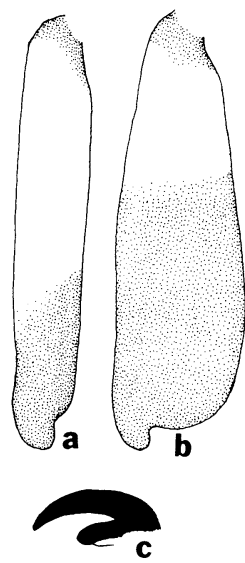

12

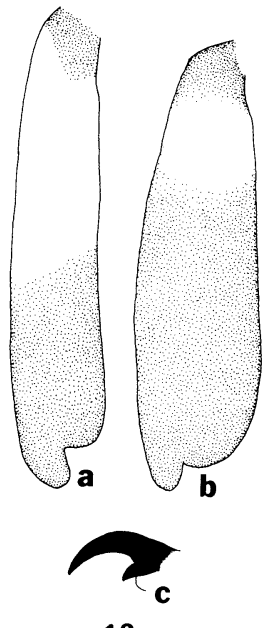

13

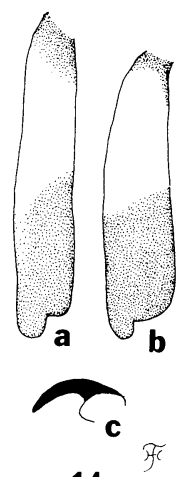

14

Figs. 9-14 Hind basitarsi and tarsal claws: 9, S. disneyi; 10, S. sulawesiense; 11, S. torautense; $12, S$. rosemaryae; $13, S$. dumogaense; $14, S$. tumpaense. a, hind basitarsus of female; $\mathrm{b}$, hind basitarsus of male; c, female tarsal claw. Scales $0.2 \mathrm{~mm}$ for basitarsi, and $0.02 \mathrm{~mm}$ for tarsal claws. 


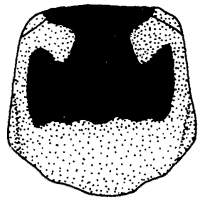

15

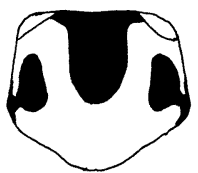

a

17

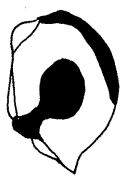

b

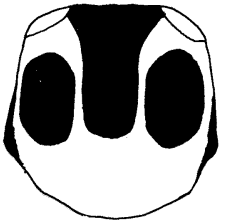

a

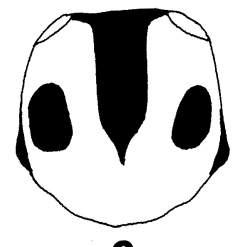

C

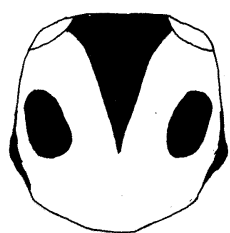

b

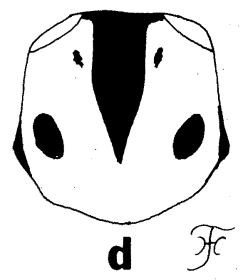

16

Figs. 15-17 Scutal patterns of male adults: 15, S. torautense; 16, S. dumogaense. a-d, showing different patterns; $17, S$. tumpaense. a, dorsal view; b, lateral view. Scale $0.5 \mathrm{~mm}$.

lateral and ventral surface. Cercus (Fig. 18c) semilunar in lateral view, about $1 / 2 \times$ as long as wide, and moderately setose. Spermatheca (Fig. 18b) ellipsoidal, about $1.4 \times$ as long as wide, well sclerotized except small area of tubular base unsclerotized, and with minute internal setae.

Male, pupa and larva: Unknown.

Type specimen: Holotype female (BMNH), slide mounted, SULAWESI: Dumoga-Bone, Project Wallace Camp area, captured by light trap, R. H. L. Disney, Sept. 1985.

Ecological notes: Unknown except the fact that the gravid female was caught by light trap. Distribution: Sulawesi.

Remarks: This new species is named after Dr. R. H. L. Disney who collected this species. This is assigned to the subgenus Morops, because hairs are present on both katepisternum and pleural membrane. This species seems close to $S$. (M.) liliwense Takaoka, 1983 and S. (M.) salazarae Takaoka, 1983 from the Philippines in having the small number of hairs on the pleural membrane, dark coloration of the hind tibia, and similar genitalia. However, it differs from the latter two species by the small sensory vesicle (its length against length of 3rd segment of maxillary palp: $1 / 4$ versus $1 / 2.6$ or $1 / 2.8$ ), and by the small number of inner teeth on the mandible ( 24 versus 28 or 30 ).

\section{Subgenus Gomphostilbia Enderlein}

\section{Simulium (Gomphostilbia) sulawesiense sp. nov.}

Female. Body length $2.5 \mathrm{~mm}$. Wing length $1.8 \mathrm{~mm}$. Head. Slightly narrower than width of thorax. Frons brownish black, semishiny, whitish grey pruinose, and covered densely with whitish yellow appressed pubescence; frontal ratio 1.9:1.0:2.0; frons-head ratio 1.0:3.6. Clypeus brownish black, semishiny, whitish grey pruinose, and densely covered with whitish yellow appressed pubescence. Antenna composed of $2+9$ segments, brown except scape, 

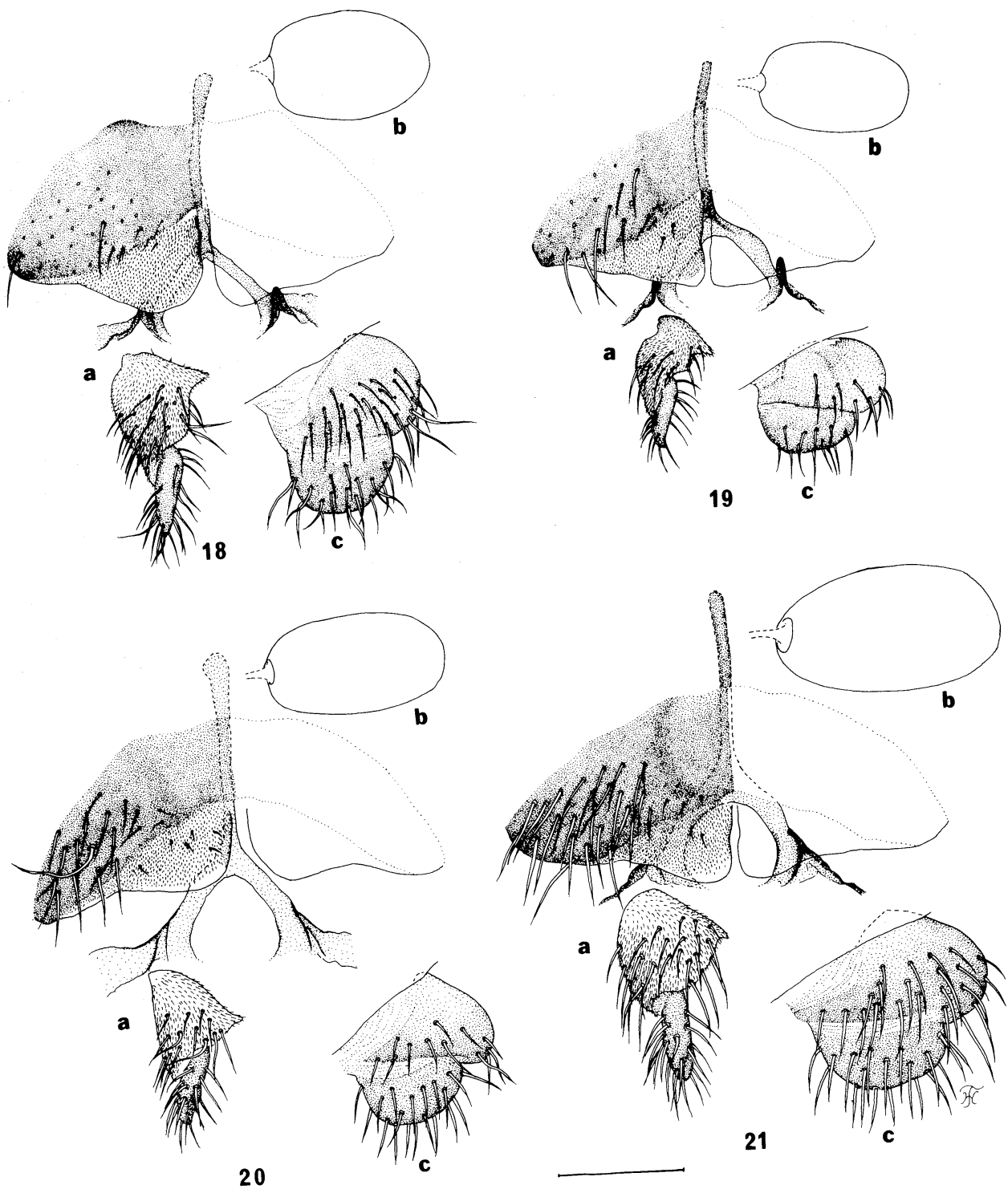

Figs. 18-21 Female genitalia: 18, S. disneyi; 19, S. sulawesiense; 20, S. torautense; 21, S. rosemaryae. a, 8th sternite, anterior gonapophyses, genital fork, paraproct and cercus in situ (ventral view); b, spermatheca; c, paraproct and cercus in side view.

Scale $0.1 \mathrm{~mm}$. 
pedicel and base of 1st flagellar segment yellow. Maxillary palp with 5 segments, proportion of 3rd, 4th and 5th segments in length 1.0:1.03:1.9; 3rd segment normal in shape and size, and with sensory vesicle which is about $1.5 \times$ as long as wide, and $1 / 5 \times$ as long as $3 \mathrm{rd}$ segment (Fig. 2). Maxilla serrated on both sides, with 6 inner teeth and 12 outer ones. Mandible serrulated only on inner side with 16 teeth and smooth on outer margin. Cibarium without denticles. Thorax. Scutum faintly whitish grey pruinose on brownish background, and densely covered with whitish yellow appressed pubescence. Scutellum dark brown, faintly whitish grey pruinose, and with hairs (but all lost, then their size and color unknown). Postscutellum brownish black, faintly whitish grey pruinose, and bare. Pleural membrane bare. Katepisternum longer than deep, and with several dark hairs. Legs. Fore coxa whitish yellow, mid coxa dark brown and hind one brown. All trochanters brown except hind one whitish yellow. All femora brown with distal $1 / 3$ of hind femur dark brown. Fore tibia brown with median portion largely somewhat pale brown on outer surface. Mid tibia brown with basal $1 / 6$ white. Hind tibia white on basal $1 / 3$, then gradually darkened towards distal $1 / 3$ and dark brown on distal $1 / 3$, and densely covered with white appressed pubescence on posterior and lateral surfaces of basal $1 / 2$ of its shaft. Fore tarsi dark brown, and basitarsus cylindrical, $6.0 \times$ as long as its greatest width. Mid tarsi dark brown. Hind tarsi dark brown to brownish black except basal $2 / 3$ of basitarsus (though base of basitarsus brown) and basal $1 / 2$ of 2nd segment white; basitarsus (Fig. 10a) narrow, nearly parallelsided. Calcipala well developed, about $2 / 3 \times$ as wide as distal portion of basitarsus, and its tip reaching distal $1 / 3$ of 2 nd segment. Pedisulcus well developed. Claw with basal tooth,

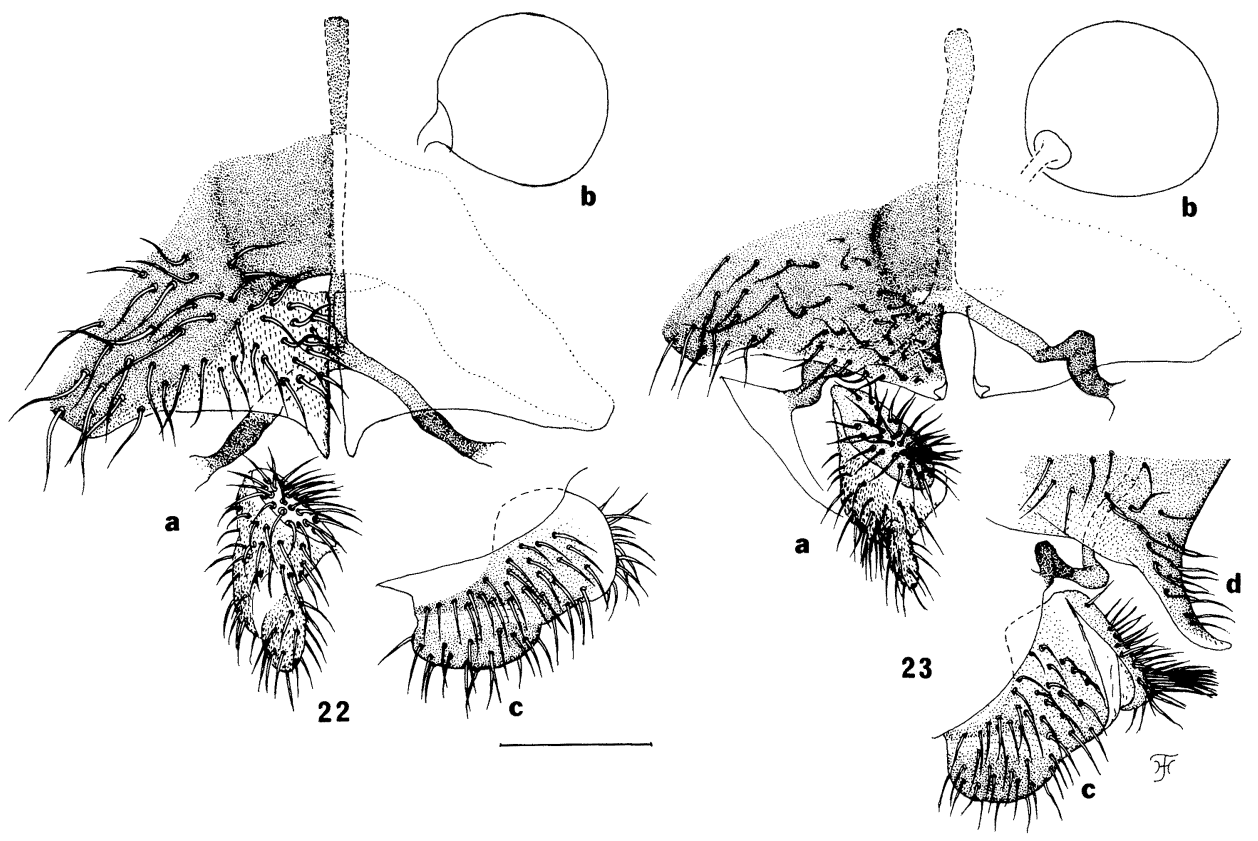

Figs. 22 and 23 Female genitalia: 22, S. dumogaense; 23, S. tumpaense. a, 8th sternite, anterior gonapophyses, genital fork, paraproct and cercus in situ (ventral view); b, spermatheca; c, paraproct and cercus in side view; d, submedian lobe of 8th sternite with anterior gonapophysis in side view. Scale $0.1 \mathrm{~mm}$. 

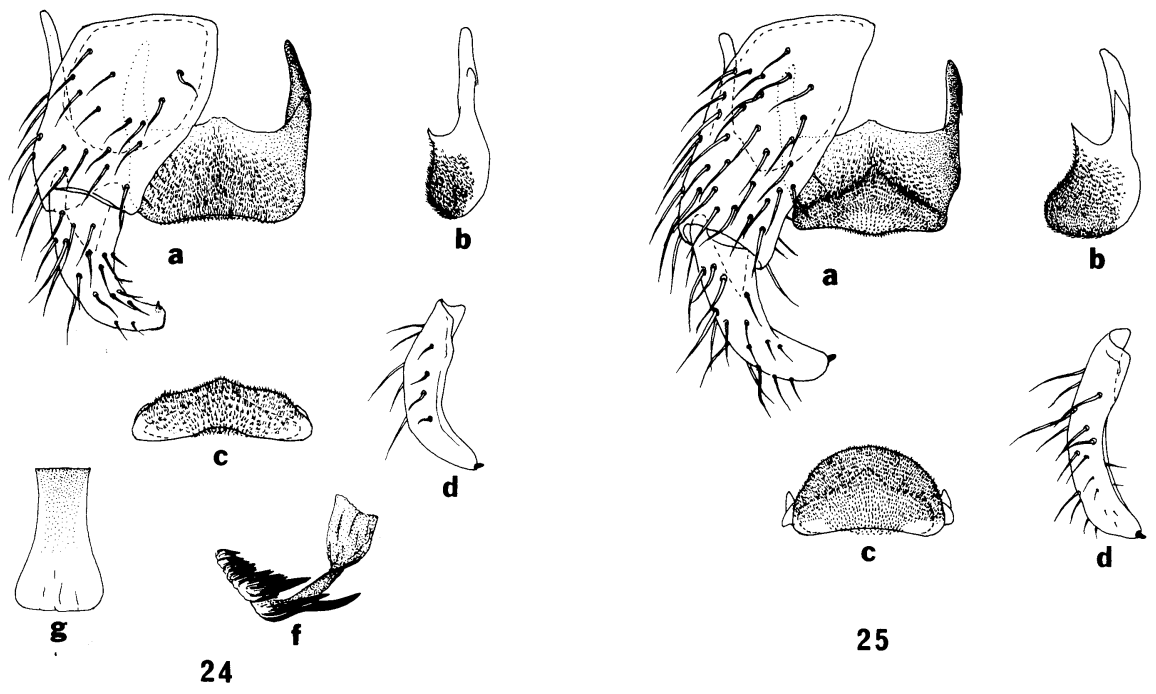

25
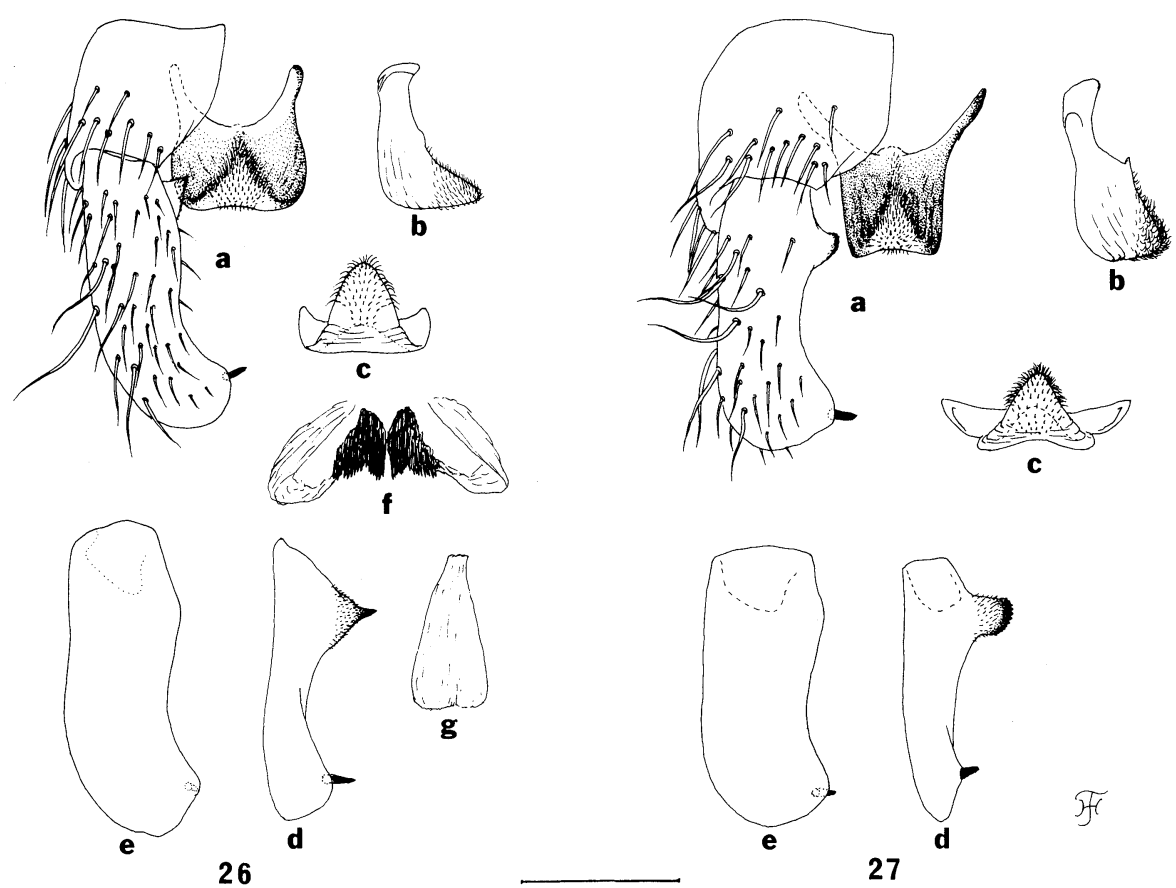

Figs. 24-27 Male genitalia: 24, S. torautense; 25, S. rosemaryae; $26, S . \quad$ dumogaense; $27, S$. tumpaense. a, coxite, style and ventral plate in situ (ventral view); b, ventral plate in side view; c, ventral plate in end view; d, style in side view; e, style viewed from ventrolaterally; f, paramere; g, median sclerite. Scale $0.1 \mathrm{~mm}$. 


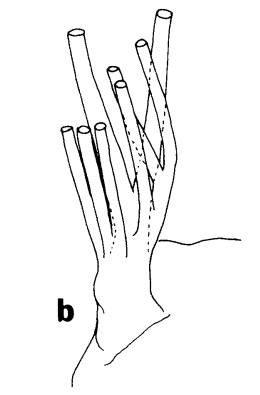

28

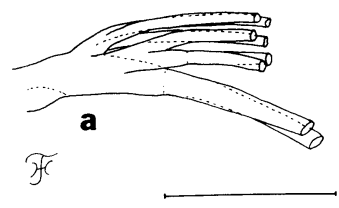

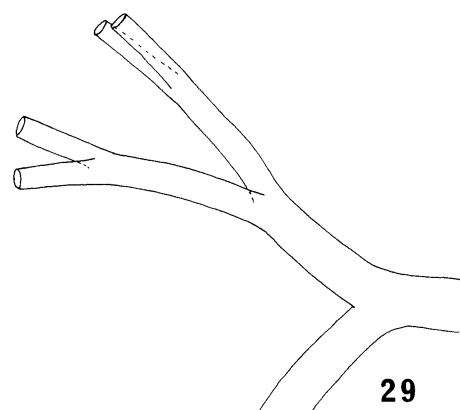

29

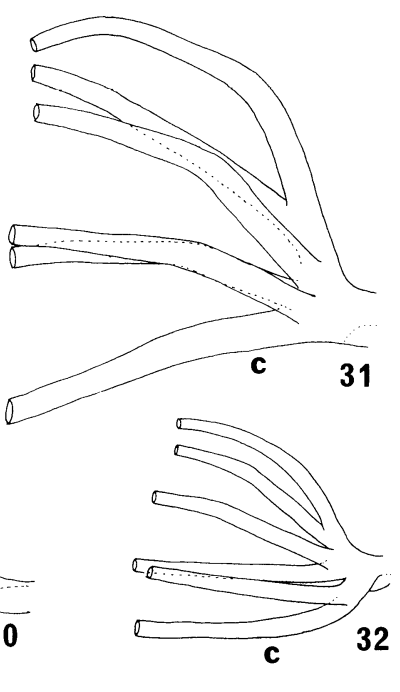

Figs. 28-32 Basal portion of pupal gills: 28 , S. torautense; 29, S. rosemaryae; 30, S. sp B; 31, S. dumogaense; 32, S. tumpaense. a, dorsal view; $\mathrm{b}$, inside view; c, outside view. Scale $0.3 \mathrm{~mm}$.

which is $1 / 2 \times$ length of claw (Fig. 10c). Wing. C with spinules and hairs. Sc haired throughout its length on undersurface. Basal section of $\mathrm{R}$ haired. $\mathrm{R}_{1}$ with spinules and hairs. $\mathrm{R}_{2}$ with dark hairs. Basal cell absent. Haltere white, with petiole dark. Abdomen. Basal scale ocherous with white hair fringe. Dorsal surface of abdominal segments dark brown to brownish black except 2nd segment pale, and sparsely covered with dark hairs; tergites of segments 6-8 shiny. Genitalia. Sternite 8 bare medially and with about 18 stout hairs laterally on each side. Anterior gonapophysis simple, membraneous, and with a few short hairs as well as numerous microsetae; inner margin moderately sclerotized; posteromedial corner rounded and transparent (Fig. 19a). Genital fork (Fig. 19a) reversed-Y shaped, with well sclerotized stem; arms diverged laterally, with well sclerotized distal ridge which is produced anteriorly. Paraproct (Figs. 19a, c) simple, with about 10 stout hairs on lateral and ventral surface. Cercus (Fig. 19c) semilunar in lateral view, about $1 / 2 \times$ as long as wide, and moderately setose. Spermatheca (Fig. 19b) ellipsoidal, about $1.7 \times$ as long as wide, well sclerotized except small area of tubular base unsclerotized, and with minute internal setae. Male, pupa and larva: Unknown.

Type specimen: Holotype female (BMNH), slide mounted, SULAWESI: Dumoga-Bone, Project Wallace Base Camp area, caught by light trap, R. H. L. Disney, Aug. 1985.

Ecological notes: The breeding habitats are unknown.

Remarks: This new species seems close to $S$. (G.) miblosi Takaoka, 1983 from Mindanao Island in the Philippines in having mandible devoid of teeth on the outer margin, small sensory vesicle and somewhat enlarged calcipala. However $S$. (G.) sulawesiense sp. nov. is different from the latter species by the fore and mid tibiae which are almost brown in this new species but are yellowish white on the basal $1 / 2$ or more in the latter. In addition, the number of stout hairs on the sternite 8 greatly differs between the two species (ca. 40 versus 100). 
This species has also some similarities to $S$. $(G$.) ceylonicum (Enderlein), 1921 from Sri Lanka in the feature of the female mandible, and the shape and coloration of hind leg (Davies and Györkös, 1987). However, in the latter species, the greatest width of frons is much narrower than the height of frons (1.0:1.35) and the sensory vesicle is large $(1 / 2 \times$ length of 3rd segment of palps). Further, this new species seems related to $S$. ( $G$.) dola Davies and Györkös, 1987 from Sri Lanka in having the similar female mandible, small sensory vesicle and wide frons. However, there are differences in the shape of the hind femur, the coloration of the hind tibia and the tarsal claw ratio to its tooth which separate this species from $S$. $(G$.) dola.

Simulium (Gomphostilbia) torautense sp. nov.

Female. Body length $2.3-2.7 \mathrm{~mm}$. Wing length $1.8-2.0 \mathrm{~mm}$. Head. Slightly narrower than width of thorax. Frons brownish black, semishiny, whitish grey pruinose, and covered densely with whitish yellow appressed pubescence; frontal ratio 1.3:1.0:2.5; frons-head ratio 1.0:5.8. Clypeus brownish black, semishiny, whitish grey pruinose, and densely covered with
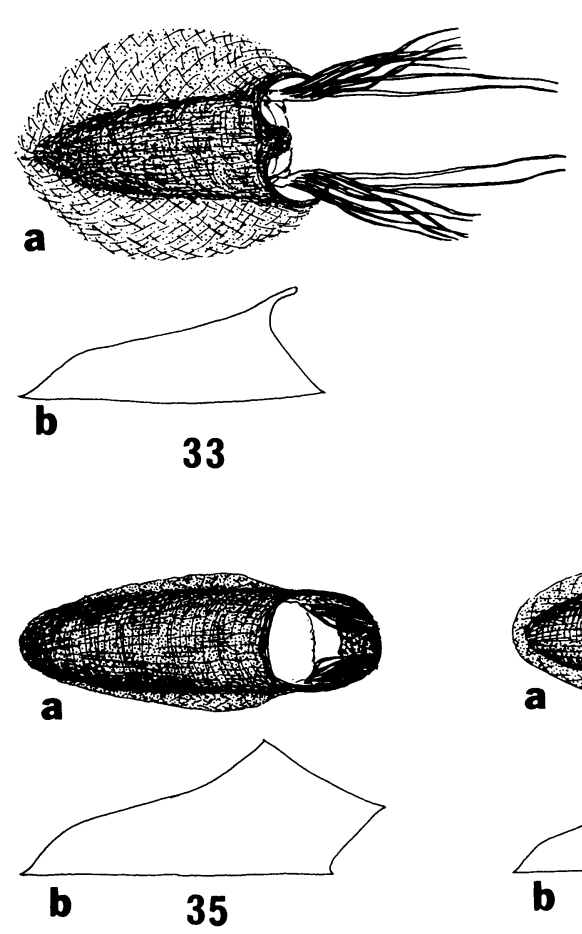

Figs. 33-39 Pupae and cocoons (Figs. 33-36) and terminal hooks of pupal abdomen (Figs. 37-39): 33 and $37, S$. torautense; 34 and 39, S. rosemaryae; $35, S$. dumogaense; 36, S. tumpaense; $38, S$. sp. B. a, dorsal view of pupa and cocoon; b, side view of cocoon. Scales $2.0 \mathrm{~mm}$ for pupae and cocoons, and $0.1 \mathrm{~mm}$ for terminal hooks. 

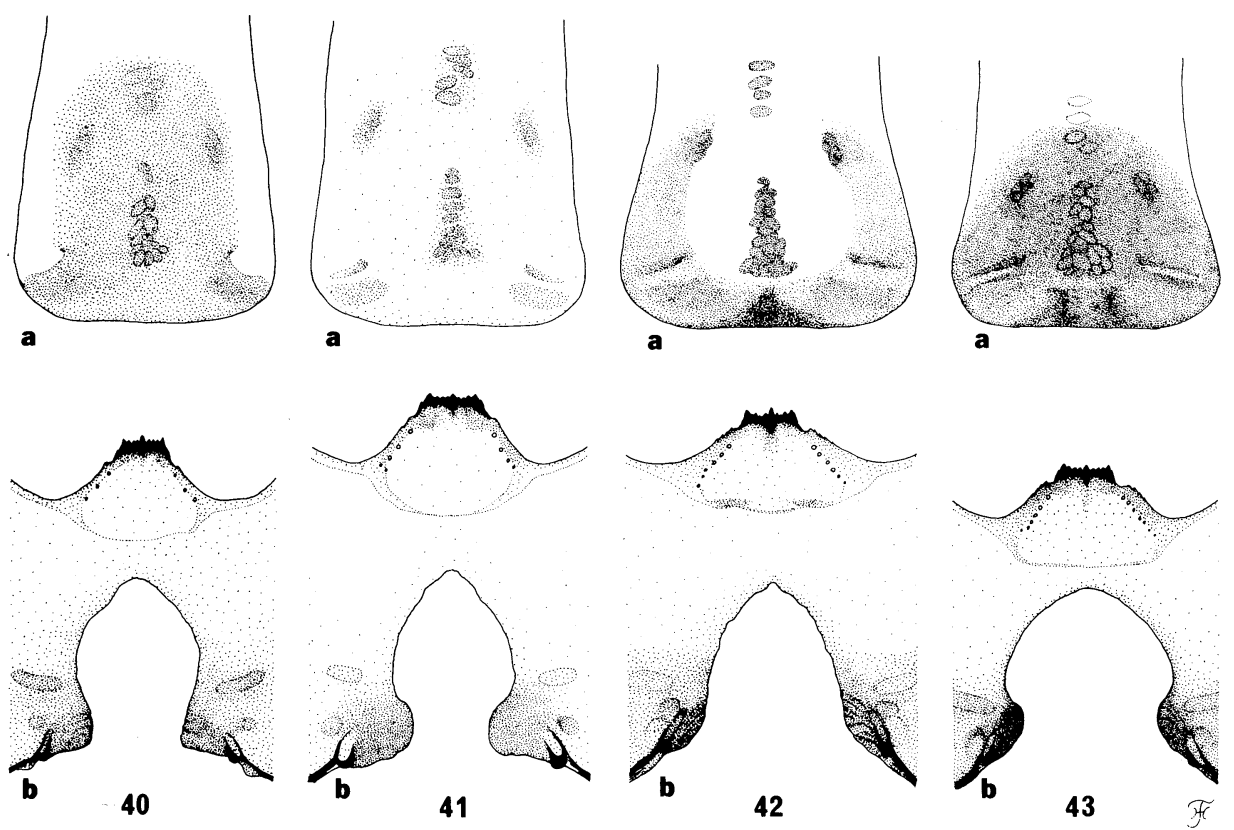

Figs. 40-43 Larval head capsules: 40, S. torautense; 41, S. rosemaryae; 42, S. dumogaense; $43, S$. tumpaense. a, cephalic apotome; b, hypostomium and postgenal cleft. Scale $0.2 \mathrm{~mm}$.

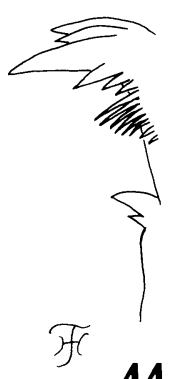

44

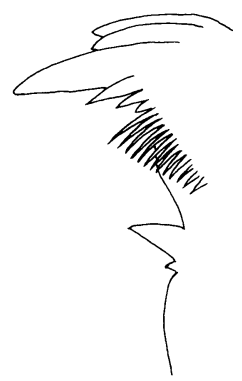

45

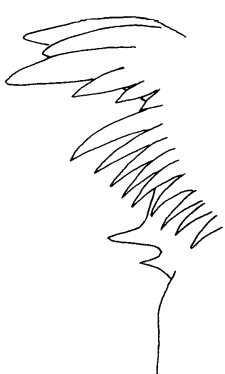

46

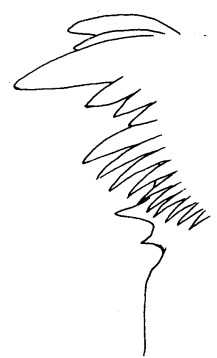

47

Figs. 44-47 Tips of larval mandibles: 44, S. torautense; 45, S. rosemaryae; 46, S. dumogaense; 47, S. tumpaense. Scale $0.05 \mathrm{~mm}$. 
whitish yellow appressed pubescence. Antenna composed of $2+9$ segments, brown except scape, pedical and base of 1st flagellar segment yellow. Maxillary palp with 5 segments, proportion of 3rd, 4th and 5th segments in length 1.0:1.1:2.3; 3rd segment normal in shape and size, and with medium-sized ellipsoidal sensory vesicle which is about $2.3 \times$ as long as wide, and about $1 / 2.5 \times$ as long as 3rd segment (Fig. 3). Maxilla serrated on both sides, with 11 teeth on each side. Mandible serrulated on both sides, with 9 or 10 outer teeth and about 25 inner ones. Cibarium without denticles. Thorax. Scutum faintly whitish grey pruinose on brownish black to black background, with 3 faintly discernible longitudinal black vittae (1 medially and 2 submedially); scutum densely covered with whitish yellow appressed pubescence, intermingled with brown ones. Scutellum dark brown, faintly whitish grey pruinose, and with long and short upstanding dark hairs. Postscutellum brownish black, faintly whitish grey pruinose, and bare. Pleural membrane bare. Katepisternum longer than deep, and with numerous whitish yellow hairs intermixed with dark hairs. Legs. Fore coxa yellow, and mid and hind coxae brownish black. All trochanters dark brown to brownish black. All femora dark brown to brownish black. Fore tibia brownish black with median portion largely pale brown on outer surface, and covered densely with white appressed pubescence on outer surface of basal $3 / 5$ of its shaft; mid and hind tibiae brownish black except extreme base whitish yellow (basal pale portion of hind tibia more distinct than that of mid one, occupying basal $2 / 5$ on posterior surface, thus bearing its border with dark area oblique in lateral view), and densely covered with white appressed pubescence on posterior and lateral surfaces of basal $3 / 5$ of their shaft; Fore tarsi black; basitarsus cylindrical, $5.9 \times$ as long as its greatest width, and with sparse dorsal hair crest. Mid tarsi brownish black to black except basal $1 / 2$ of basitarsus whitish yellow. Hind tarsi brownish black to black except basal $5 / 8$ of basitarsus (though base of basitarsus brownish black) and basal $1 / 2$ of 2nd segment white; basitarsus (Fig. 11a) narrow, nearly parallel-sided. Calcipala and pedisulcus well developed. Claw with basal tooth, which is $1 / 2 \times$ length of claw (Fig. 11c). Wing. C with spinules and hairs. Sc with several hairs on basal $1 / 2$ on undersurface. Basal section of $\mathrm{R}$ haired. $\mathrm{R}_{1}$ with spinules and hairs. $R_{2}$ with dark hairs. Basal cell absent. Hair tuft of stem vein brownish black. Haltere white, with petiole dark.

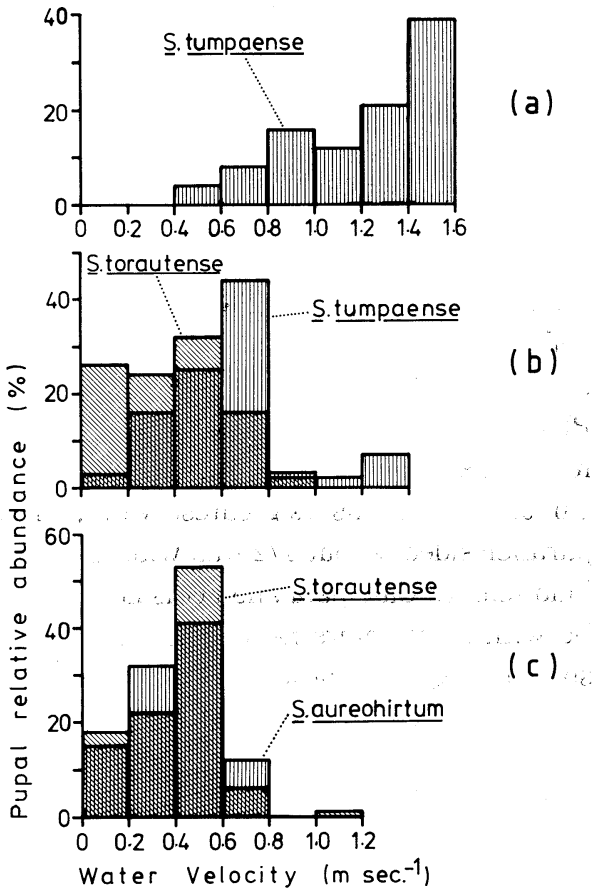

Fig. 48 Water velocity preferences for three species of blackflies: -a) S. tumpaense in the R. Tumpah; b) S. torautense and $S$. tumpaen$s e$ in a stream flowing into the R. Toraut; c) $S$. torautense and $S$. aureohirtum in a second stream flowing into the R. Toraut. 
Abdomen. Basal scale dark brown to brownish black with white hair fringe. Dorsal surface of abdominal segments dark brown to brownish black except basal 2/3 of 2nd segment pale brown, and sparsely covered with dark hairs; tergite of 2 nd segment broadly white pruinose; tergites of segments 6-8 shiny. Genitalia. Sternite 8 bare medially and with about 18 stout hairs laterally on each side. Anterior gonapophysis simple, membraneous, and with several short hairs as well as numerous microsetae; inner margin moderately sclerotized; poster omedial corner largely rounded and transparent (Fig. 20a). Genital fork (Fig. 20a) reversedY shaped, with well sclerotized stem; arms diverged laterally, and with no projection. Paraproct (Figs. 20a, c) simple, with about 12 stout hairs on lateral surface. Cercus (Fig. 20c) semilunar in lateral view, $2 / 5 \times$ as long as wide, and moderately setose. Spermatheca (Fig. 20b) ellipsoidal, about $1.8 \times$ as long as wide, well sclerotized except small area of tubular base unsclerotized, and with minute internal setae.

Male. Body length 2.5-2.8 mm. Wing length $1.8-1.9 \mathrm{~mm}$. Head. Width slightly wider than thorax. Holoptic; upper eye consisting of 15 horizontal rows and 15 vertical columns of large facets on each side. Face brownish black, and silvery white pruinose. Clypeus brownish black, silvery white pruinose and densely covered with whitish yellow pubescence interspersed with dark hairs. Antenna composed of $2+9$ segments, yellowish brown to brown except scape, pedicel and base of 1st flagellar segment yellow; 1st flagellar segment elongated, about $1.6 \times$ as long as 2 nd flagellar segment. Maxillary palp with 5 segments, proportion of $3 \mathrm{rd}, 4$ th and 5th segments in length 1.0:1.3:3.1; 3rd segment not enlarged and with small sensory vesicle. Thorax. Scutum brownish black, with shiny, faintly-whitish grey pruinose pattern as shown in Fig. 15, and uniformly covered with bright brassy appressed pubescence (though relpaced by whitish yellow appressed pubescence on shoulders, and intermixed with whitish yellow pubescence on prescutellar area). Scutellum dark brown to brownish black, with long and short dark hairs. Postscutellum brownish black, faintly whitish grey pruinose, and bare. Pleural membrane bare. Katepisternum with numerous dark hairs. Legs. Colourd as in female except tibial pale portions less distinct than female. Fore basitarsus almost cylindrical, $6.1 \times$ as long as its greatest width, and with sparse hair crest. Hind basitarsus (Fig. 11b) parallel-sided, about $1 / 2 \times$ as wide as greatest width of hind tibia which is equal to that of hind femur. Calcipala and pedisulcus well developed. Wing. $\mathrm{C}$ with spinules and dark hairs. $\mathrm{Sc}$ with a few hairs near base. Basal section of $\mathrm{R}$ fully haired. $\mathrm{R}_{1}$ with a single row of spinules. $\mathrm{R}_{2}$ with dark hairs. Basal cell absent. Hair tuft of stem vein dark brown. Haltere dark creamy, with petiole dark. Abdomen. Basal scale brownish black with dark hair fringe. Dorsal surface of abdomen brownish black, and sparsely covered with dark hairs; tergite of segment 2 broadly white pruinose, tergites of 5,6 and 7 each with a pair of shiny, faintly-grey pruinose patches laterally. Genitalia. Coxite (Fig. 24a) nearly rectangular in ventral view, and about $1.4 \times$ as long as its greatest width. Style (Fig. $24 \mathrm{~d}$ ) small, about $4 / 5 \times$ as long as coxite, strongly curved dorsomedially at distal $1 / 3$, and with a single apical spine. Body of ventral plate flat (Fig. 24a), rectangular in ventral view, about $1 / 2 \times$ as long as its width, slightly concave on posterior margin, slightly produced ventrally forming very low posteromedial process, and densely covered with microsetae ventrally, posteriorly and dorsomedially; basal arms of moderate size, directed forwardly and slightly inwardly. Paramere (Fig. 24f) of moderate size, and with 3 long hooks and 8-10 shorter ones. Median sclerite (Fig. 24g) broad, plate-like, somewhat divergent distally and ended roundly.

Pupa. Body length (excluding gill filaments) $2.5-2.9 \mathrm{~mm}$. Head and thorax. Integument 
yellowish brown, covered moderately with tubercles. Head with 1 facial pair and 3 frontal pairs of simple trichomes. Thorax with 5 pairs of simple, slender trichomes. Gill (Figs. 28a, b) with 8 filaments arranged in 3, 3, 2 groups from above downwards; dorsal triplet group very shortly stalked or even sessile, giving rise to 3 filaments, of which 2 filaments usually arranged in pair, having very short secondary stalk; middle triplet group arising inwardly from dorsolateral surface of main stalk a little distal to base of dorsal triplet, shortly stalked, and giving rise to 2 paired filaments (very shortly stalked) and 1 isolated filament; ventral pair of filaments shortly stalked, much longer and thicker than other 6 filaments in dorsal and middle groups which are almost the same in size (length $3.0-3.8 \mathrm{~mm}$ versus $1.8-2.6 \mathrm{~mm}$ ); all filaments tapering toward tip, with numerous sharp transverse ridges, and covered densely with minute tubercles. Abdomen. Tergum 1 pale ocherous, with 2 simple setae (1 long and the other short and very slender) on each side, and covered with no tubercles. Tergum 2 pale ocherous, with 5 simple short setae and 1 simple long seta on each side. Terga 3 and 4 each with 4 hooked spines along posterior margin on each side. Tergum 5 lacking spine-combs. Terga 6-9 each with spine-combs on each side. Tergum 9 with a pair of simple terminal hooks (Fig. 37). Sternum 5 with 2 simple hooks submedially on each side. Sterna 6 and 7 each with 2 simple hooks widely spaced ( 1 submedially and the other laterally) on each side. Last segment with a few grapnel-like hooklets ventrolaterally. Cocoon (Figs. 33a, b) wall pocket-shaped, closely woven, extending ventrolaterally forming wide flange, bearing thick anterior margin and with small to medium anterodorsal projection.

Mature larva. Body length 4.7-5.0 mm. Body with transverse, sepia bands dorsally, each on thoracic segments 1-3 (though band on segment 2 indistinct in most specimens), and abdominal segments 1-4, and almost entirely sepia dorsally on abdominal segments 5-8 (though medially discolored to varying extents in most specimens). Cephalic apotome (Fig. 40a) more or less largely darkened except narrow lateral portions and anterior portion whitish yellow; head spots different in darkness against dark background, from much darker than, or as dark as, background (then positive), to lighter than background (then negative); further, in some larvae, some spots positive while others negative. Antenna composed of 4 segments, and longer than stem of cephalic fan; proportional length of segments 1-31.3:1.1:1.0. Cephalic fan with about 34 main rays. Mandible (Fig. 44) with normal arrangement of teeth, and without supernumerary mandibular serrations. Hypostomium (Fig. 40b) with a row of 9 apical teeth; medial tooth longest, followed by corner teeth, and 3 intermediate teeth (almost equal in size) on each side shortest; lateral margin smooth; hypostomial setae 3 or 4 in number, lying subparallel to side margins. Postgenal cleft (Fig. 40b) deep, about $4.5 \times$ as long as postgenal bridge, widest in the middle and somewhat constricted at base. Thoracic cuticle bare. Abdominal cuticle moderately covered with simple minute spines dorsally on segments 5-8. Rectal gill lobes compound, each lobe with 5-7 finger-like secondary lobules. Anal sclerite of usual $\mathrm{X}$-form, with posterior arms about $1.2 \times$ as long as anterior ones, and broadly sclerotized at base between anterior and posterior arms. Ventral papillae well developed. Posterior circlet with about 68 rows of about 12 hooks.

Type specimens: Holotype female $(\mathrm{BMNH})$, slide-mounted; allotype male; paratypes, 6 females, 8 males, 67 pupae and 10 mature larvae, SULAWESI: Dumoga-Bone Reserve, tributaries of R. Toraut, D. M. Roberts, Sept. 1985.

Ecological notes: This was the dominant species in the small tributaries (1-5 m wide) flowing into the R. Toraut in the Domoga Valley and was found in moderate velocities up to $0.6 \mathrm{~m} /$ 
sec. (Fig. 40). Small numbers were also found in slow-flowing stretches of the R. Tumpah up to altitudes of $550 \mathrm{~m}$. Most were found attached to trailing grass, only a few on rocks. It was associated with $S$. $(N$.) aureohirtum, $S$. (S.) tumpaense and $S$. $(G$.) rosemaryae. None was found around Lake Mooat (1,100 $\mathrm{m}$ altitude).

Distribution: Sulawesi.

Remarks: This new species seems closely related to $S$. (G.) batoense Edwards, 1934 from East Java, S. (G.) siamense Takaoka and Suzuki, 1984 from Thailand, and S. (G.) krombeini Davies and Györkös, 1987 from Sri Lanka, in having the dark coloration of the legs, parallelsided male hind basitarsus, and deep larval postgenal cleft. However, this species is easily distinguished from these species by the presence of anterodorsal projection on the cocoon (Figs. 33a, b) and the branching of the pupal respiratory filaments (Figs. 28a, b).

\section{Simulium (Gomphostilbia) rosemaryae sp. nov.}

Female. Body length $2.5-2.8 \mathrm{~mm}$. Wing length $2.4-2.5 \mathrm{~mm}$. Head. Slightly narrower than width of thorax. Frons brownish black, faintly-whitish grey pruinose, and covered densely with whitish yellow appressed pubescence interspersed with dark hairs; frontal ratio 1.35: 1.0:2.0; frons-head ratio 1.0:5.2. Clypeus brownish black, semishiny, whitish grey pruinose, and densely covered with whitish yellow appressed pubescence, interspersed with several dark long hairs. Antenna composed of $2+9$ segments, brown except scape, pedicel and base of 1st flagellar segment yellow. Maxillary palp with 5 segments proportion of 3rd, 4th and 5th segments in length 1.0:1.0:2.4; 3rd segment (Fig. 4) normal in shape and size, and with medium-sized, ellipsoidal sensory vesicle which is about $2.0 \times$ as long as wide, and $1 / 3 \times$ as long as 3rd segment. Maxilla serrated on both sides, with 16 outer teeth and 11 inner ones. Mandible serrulated on both sides, with 13 outer teeth and about 30 inner ones. Cibarium without denticles. Thorax. Scutum brownish black, with shiny, faintly whitish grey pruinosity, and densely covered with whitish yellow appressed pubescence, intermingled with brassy appressed pubescence. Scutellum dark brown, faintly-whitish grey pruinose, and with long and short upstanding dark hairs. Postscutellum brownish black, faintly-whitish grey pruinose, and bare. Pleural membrane bare. Katepisternum longer than deep, and with numerous dark hairs, interspersed with whitish yellow pubescence. Legs. Fore coxa pale yellow, and mid and hind coxae brownish black. All trochanters dark brown except hind one pale yellow. All femora dark brown to brownish black. Fore tibia white except distal 1/4 brownish black; mid tibia white except distal $1 / 3$ brownish black; hind tibia white on basal $1 / 2$, gradually darkened towards distal $1 / 4$, and brownish black on distal $1 / 4$; all tibiae covered with white appressed pubescence on basal $2 / 3$ or $3 / 4$. Fore tarsi black; basitarsus nearly cylindrical, $5.0 \times$ as long as its greatest width, and with sparse dorsal hair crest. Mid tarsi black except basal $1 / 3$ of basitarsus whitish yellow (its border not well defined). Hind tarsi black except basal 2/3 of basitarsus (though base of basitarsus brownish black) and base of 2nd segment white; basitarsus (Fig. 12a) narrow, nearly parallel-sided. Clacipala and pedisulcus well developed. Claw (Fig. 12c) with basal tooth, which is $1 / 2 \times$ length of claw. Wing. $\mathrm{C}$ with spinules and dark hairs. Sc almost fully haired. Basal section of $\mathrm{R}$ haired. $\mathrm{R}_{1}$ with spinules and dark hairs. $\mathrm{R}_{2}$ with dark hairs. Basal cell absent. Hair tuft of stem vein brownish black. Haltere white. Abdomen. Basal scale dark brown to brownish black with white hair fringe. Dorsal surface of abdominal segments dark brown to brownish black except basal 1/2 of 2nd segment whitish yellow to pale yellowish brown, and sparsely covered 
with dark hairs and pale pubescence; tergite of 2 nd segment broadly white pruinose; tergites of segments 6-8 shiny. Genitalia. Sternite 8 bare medially and with about 26 stout hairs laterally on each side. Anterior gonapophysis simple, membraneous, and with a few short hairs as well as numerous microsetae; inner margin slightly concave medially, and narrowly sclerotized; posteromedial corner rounded and transparent (Fig. 21a). Genital fork (Fig. 21a) reversed-Y shaped, with well sclerotized stem; arms broad, diverged laterally, and with no marked projection. Paraproct (Figs. 21a, c) simple, with about 20 stout hairs on lateral surface. Cercus (Fig. 21c) semilunar in lateral view, $2 / 5 \times$ as long as wide, and moderately setose. Spermatheca (Fig. 21b) ellipsoidal, about $1.8 \times$ as long as wide, unpatterned, and well sclerotized except small area of tubular base unsclerotized.

Male. Boby length 2.8-3.0 mm. Wing length $2.4-2.5 \mathrm{~mm}$. Head. Width slightly wider than thorax. Holoptic; upper eye consisting of 13 horizontal rows and 10 vertical columns of large facets on each side. Face brownish black, and silvery white pruinose. Clypeus brownish black, silvery white pruinose and densely covered with whitish yellow pubescence interspersed with dark hairs. Antenna composed of $2+9$ segments, yellowish brown to brown except scape, pedicel and base of 1st flagellar segment yellow; 1st flagellar segment elongated, about $1.8 \times$ as long as 2 nd flagellar segment. Maxillary palp with 5 segments, proportion of 3rd, 4th and 5th segments in length 1.0:1.2:3.2; 3rd segment not enlarged and with small sensory vesicle. Thorax. Scutum brownish black, with semishiny, faint, whitish grey pruinose pattern similar to that of $S$. $(G$.) torautense (although less distinct) and uniformly covered with whitish yellow to yellow appressed pubescence intermixed with brassy one. Scutellum dark brown to brownish black, with long and short dark hairs. Postscutellum brownish black, faintly whitish grey pruinose, and bare. Pleural membrane bare. Katepisternum with numerous dark hairs interspersed with whitish yellow ones. Legs. Fore coxa yellow, mid and hind coxae brownish black. All trochanters brownish black except hind one yellowish brown. Fore tibia white except basal small area pale brown and distal $1 / 3$ brownish black, and covered densely with white appressed pubescence on basal $4 / 5$; mid tibia brownish black except basal $2 / 5$ white; hind tibia brownish black except basal $1 / 3$ white; white areas of mid and hind tibiae covered with white appressed pubescence. Fore tarsi black; basitarsus almost cylindrical, $6.1 \times$ as long as its greatest width, and with sparse hair crest. Mid tarsi black except basal $1 / 4$ whitish yellow (though its border not well defined). Hind tarsi black except basal $2 / 5$ and a little more of basitarsus and base of 2 nd segment white (though base of basitarsus dark brown); hind basitarsun (Fig. 12b) expanded, wedge-shaped in lateral view, $3 \times$ as long as its greatest width, and equal in width to hind tibia which is about $1.4 \times$ as wide as hind femur. Calcipala and pedisulcus well developed. Wing. $\mathrm{C}$ with spinules and dark hairs. Sc bare or with a few hairs near base. Basal section of $\mathrm{R}$ fully haired. $\mathrm{R}_{1}$ with a single row of spinules. Basal cell absent. Hair tuft of stem vein dark brown. Haltere dark creamy. Abdomen. Basal scale brownish black with dark hair fringe. Dorsal surface of abdomen brownish black except basal $1 / 2$ of segment 2 dark yellow to pale brown, and sparsely covered with dark hairs; tergite of segment 2 broadly white pruinose; tergites of 5,6 and 7 each with a pair of shiny, faint, grey pruinose patches laterally. Genitalia. Coxite (Fig. 25a) nearly rectangular in ventral view, and about $2.0 \times$ as long as its greatest width. Style (Fig. 25d) small about $4 / 5 \times$ as long as coxite, gently curved dorsomedially, and with a single apical spine. Body of ventral plate (Fig. 25a) flat, rectangular in ventral view, a little longer than $1 / 2$ its width, nearly parallel-sided (although posterior $1 / 2$ somewhat narrowed), slightly 
convex medially on posterior margin, produced ventrally forming round posteromedian process, and densely covered with microsetae ventrally, posteriorly and dorsomedially; basal arms of moderate size, directed forwardly. Paramere of moderate size, and with 3 long hooks and 8-10 shorter ones. Median sclerite broad, plate-like, somewhat divergent distally and ended roundly, as in $S$. (G.) torautense.

Pupa. Body length (excluding gill filaments) $2.6-3.3 \mathrm{~mm}$. Head and thorax. Integument yellowish brown, covered densely with tubercles. Head with 1 facial pair and 3 frontal pairs of simple trichomes. Thorax with 5 pairs of simple, slender trichomes. Gill (Fig. 29c) with 6 filaments arranged in 3 pairs; ventral pair of filaments with long stalk, dorsal and middle pairs having primary stalk in common which is about $1 / 2 \times$ as long as that of ventral pair, and is divergent from the latter stalk making a right angle; secondary stalk of middle pair subequal to or a little longer than that of dorsal pair, and also subequal to their common primary stalk; all filaments subequal in length and thickness to each other, almost as long as pupal body, tapering toward tip, with numerous sharp transverse ridges, and covered densely with minute tubercles. Abdomen. All terga pale ocherous. Tergum 1 moderately tuberculate, with 1 simple long seta on each side. Tergum 2 moderately tuberculate, with 5 simple short setae and 1 simple long seta on each side. Terga 3 and 4 each with 4 hooked spines along posterior margin on each side. Tergum 5 lacking spine-combs. Terga 6-9 each with spine-combs on each side. Tergum 9 with a pair of terminal hooks, outer margin of which is serrulated (Fig. 39). Sternum 4 with 2 simple or bifid hooks submedially on each side. Sternum 5 with 2 bifid hooks submedially on each side. Sterna 6 and 7 each with 2 hooks widely spaced (1 submedially-situated hook bifid, and the other laterally-situated simple or bifid) on each side. Last segment with a few grapnel-like hooklets ventrolaterally. Cocoon (Figs. 34a, b) wall pocket-shaped, closely woven, extending ventrolaterally forming wide flange, and bearing narrow anteroventral neck (though this neck absent in some cocoons); anterodorsal margin of opening not thickened, though slightly raised medially, but with no distinct projection.

Mature larva. Boby length 5.2-5.8 mm. Body grey, with transverse, sepia bands dorsally, each on abdominal segments 3 and 4 (though usually discontinued medially), and almost entirely sepia dorsally on abdominal segments 5-8 (though discolored medially to varying extents in most specimens). Cephalic apotome (Fig. 41a) pale, with faint positive head spots. Antenna composed of 4 segments, and longer than stem of cephalic fan; proportional length of segments 1-3 1.2:0.9:1.0. Cephalic fan with about 28 main rays. Mandible (Fig. 45) with normal arrangement of teeth, and without supernumerary mandibular serrations. Hypostomium (Fig. 41b) with a row of 9 apical teeth; median tooth as long as corner teeth, and longer than 3 intermediate teeth on each side, which are subequal in size to each other; lateral margin smooth; hypostomial setae 4 or 5 in number, lying subparallel to side margins. Postgenal cleft (Fig. 41b) deep, arrow-head shaped, about $3.6 \times$ as long as postgenal bridge, widest in the middle and markedly constricted at base. Thoracic cuticle bare. Abdominal cuticle moderately covered with branched (into 3-5) minute spines dorsally on segments 5-8. Rectal gill lobes compound, with $0-3$ finger-like secondary lobules. Anal sclerite of usual Xform, with posterior arms about $1.2 \times$ as long as anterior ones, and broadly sclerotized at base between anterior and posterior arms. Ventral papillae well developed. Posterior circlet with about 86 rows of about 13 hooks.

Type specimens: Holotype female $(\mathrm{BMNH})$, slide-mounted; allotype male, slide-mounted; 
paratypes, 10 females, 7 males, 10 pupae and 4 mature larvae, SULAWESI: tributaries of Lake Mooat (near Kotinomobagu), D. M. Roberts, Sept. 1985.

Ecological notes: This species was found in streams $(20 \mathrm{~cm}-2 \mathrm{~m}$ wide) flowing through both forest and coffee plantations into Lake Mooat (altitude of $1,100 \mathrm{~m}$ ). The streams had low velocities $(0.1-0.4 \mathrm{~m} / \mathrm{sec}$.) and the larvae were attached to dead leaves and trailing vegetation. They were found in association with $S$. (S.) dumogaense. Six pupae were also found in a small stream ( $2 \mathrm{~m}$ wide) flowing through farmland into the $\mathrm{R}$. Toraut (at an altitude of $200 \mathrm{~m}$ ).

Distribution: Sulawesi.

Remarks: This new species seems related to $S$. (G.) metatarsale Brunetti, 1911, S. (G.) tenuistylum Datta, 1973, from India, S. (G.) tokarense Takaoka, 1973, S. (G.) okinawense Takaoka, 1976 from Japan, S. (G.) inthanonense Takaoka and Suzuki, 1984 from Thailand, and S. (G.) ela Davies and Györkös, 1987 from Sri Lanka by having the enlarged, wedgeshaped male hind basitarsus (Fig. 12b). However, S. rosemaryae is readily separated from these known species and also from all the other members of the ceylonicum group by having the pupal gill with six filaments in place of eight filaments. The two Philippine species, $S$. (G.) baisasae Delfinado, 1962 and $S$. (G.) ambigens Delfinado, 1969, both belonging to different groups, have the 6 -filamented pupal gill (Takaoka, 1983). However, the shape of genitalia in both sexes, and the female claws (simple or with small tooth) are quite different from those of the present new species.

\section{Simulium (Gomphostilbia) sp. B}

Female, male, larva: Unknown.

Pupa. Body length (excluding gill filaments) $2.3 \mathrm{~mm}$. Head, thorax and abdomen similar to those of $S$. (G.) torautense except following features: Stalk of dorsal triplet of gill filaments arising upwards making a right or a little greater angle against stalk of ventral paired filaments, and stalk of middle triplet arising nearly on the same vertical plane (Fig. 30); ventral paired filaments with elongated stalk (Fig. 30), much longer and thicker than other 6 filaments in dorsal and middle groups which are almost the same in size (length about 2.8 $\mathrm{mm}$ versus $1.6 \mathrm{~mm}$ ); terminal hooks weakly serrulated near apex (Fig. 38). Cocoon similar to that of $S$. (G.) torautense but without anterodorsal projection.

Specimens examined: 3 pupae, SULAWESI: Dumoga-Bone Reserve, tributary of R. Toraut, D. M. Roberts, Sept. 1985.

Ecological notes: This species was collected together with $S .(G$.) torautense in a small tributary flowing into the R. Toraut.

Distribution: Sulawesi.

Remarks: There is a possibility that this is the pupa of $S$. $(G$.) sulawesiense which was herein described based on the only one female adult specimen. However, the identity of this species remains unsolved because of the insufficient material.

This species seems very close to $S$. (G.) sundaicum Edwards, 1934 from East Java in having the similar branching method of pupal gill filaments and simple slipper-shaped cocoon, although the female of the latter species differs from that of $S$. ( $G$.) sulawesiense by having the dark subbasal ring on the hind tibiae. 
Subgenus Simulium Latreille s. str.

Simulium (Simulium) dumogaense sp. nov.

Female. Body length $2.7-3.3 \mathrm{~mm}$. Wing length $2.7 \mathrm{~mm}$. Head. Narrower than width of thorax. Frons black, shiny, and covered with several dark hairs along lateral margins and near lower margin; frontal ratio 1.2:1.0:1.5; frons-head ratio 1.0:4.9. Clypeus black, shiny, whitish pruinose, and moderately covered with dark hairs. Antenna composed of $2+9$ segments, brown except scape, pedicel and base of 1st flagellar segment yellow. Maxillary palp with 5 segments, proportion of $3 \mathrm{rd}$, 4 th and 5 th segments in length 1.0:1.2:2.5; 3rd segment (Fig. 5) normal in shape and size, and with medium ellipsoidal sensory vesicle which is about $1.5 \times$ as long as wide; sensory vesicle with wide opening (Fig. 5). Maxilla serrated on both side, with about 15 teeth on each side. Mandible serrulated on both sides, with 14-16 outer teeth and about 30 inner ones. Cibarium with a transverse row of about 15 small denticles and a cluster of numerous small denticles on median space, as shown in Fig. 7. Thorax. Scutum brownish black to black, shiny, faintly-whitish grey pruinose and with a broad band of iridescence on each side along lateral borders; the 2 bands bent inwards near anterolateral corners; scutum uniformly covered with dark hairs. Scutellum brownish black to black, faintly-whitish grey pruinose, and with long and short upstanding dark hairs. Postscutellum brownish black to black, faintly-whitish grey pruinose, and bare. Pleural membrane and katepisternum bare. Legs. Fore coxa whitish yellow, and mid and hind coxae brownish black. All trochanters, femora and tibiae brownish black; fore tibia with whitish sheen widely on outer surface, and mid and hind tibiae also with whitish sheen on posterior surface along basal $1 / 2$ of shaft. Fore tarsi black; basitarsus dilated, about $4.1 \times$ as long as its greatest width, and with conspicuous, thick dorsal hair crest. Mid tarsi brownish black to black except basal $4 / 5$ of basitarsus and basal $1 / 2$ of 2 nd segment whitish yellow. Hind tarsi brownish black to black except basal $1 / 2$ of basitarsus (though base of basitarsus brownish black) and 2nd segment whitish yellow; basitarsus (Fig. 13a) narrow, nearly parallel-sided. Calcipala and pedisulcus well developed. Claw (Fig. 13c) with small basal tooth. Wing. C with spinules and hairs. Sc fully haired on undersurface. Basal section of $\mathrm{R}$ bare. $\mathrm{R}_{1}$ with spinules and hairs. $\mathrm{R}_{2}$ with hairs. Basal cell absent. Hair tuft on stem vein dark brown. Haltere pale white with petiole dark brown. Adbomen. Basal scale brownish black with dark hair fringe. Dorsal surface of abdominal segments brownish black to black except segment 2 brownish, and sparsely covered with dark hairs; tergite of 2nd segment with broad transverse, iridescent, silvery white pruinosity; tergites of segments 5-8 shiny. Genitalia. Sternite 8 (Fig. 22a) bare medially, and with about 24 dark long hairs on each side; posterior border of sternite 8 widely concave, and well demarcated from anterioir gonapophyses. Anterior gonapophysis (Fig. 22a) simple, membraneous, nearly triangular in shape, with short projection extending backwards on posteromedial corners, and covered sparsely with about 20 dark long hairs; inner margin nearly straight and weakly sclerotized; posterior margin thin, transparent and bare. Genital fork (Fig. 22a) reversed-Y shaped, with slender, well sclerotized stem; arms diverged laterally, and with heavily sclerotized ridge distally but having no marked projection. Paraproct (Figs. 22a, c) produced downwards, with nearly transparent rounded plate facing ventromedially, and moderately setose on lateral surface; ventromedial plate with about 25 pale slender hairs on its surface. Cercus (Fig. 22c) very short, rounded posteriorly, and moderately setose. Spermatheca (Fig. 22b) globose, and well sclerotized except small area of tubular base unsclerotized. 
Male. Body length $3.0-3.4 \mathrm{~mm}$. Wing length $2.5 \mathrm{~mm}$. Head. Width slightly narrower than thorax. Holoptic; upper eye consisting of 17 horizontal rows and 13 or 14 vertical columns of large facets on each side. Face black, and white pruinose. Clypeus black, white pruinose and sparsely covered whth dark hairs. Antenna composed of $2+9$ segments, brown except scape, pedicel and base of 1st flagellar segment yellow; 1st flagellar segment elongated about $1.7 \times$ as long as 2nd flagellar segment. Maxillary palp with 5 segments, proportion of 3rd, 4th and 5th segments in length 1.0:1.2:2.5; 3rd segment not enlarged and with small ellipsoidal sensory vesicle. Thorax. Scutum black, with brilliant iridescent, silvery white pruinosity laterally and posteriorly and in 2 narrow submedian bands extending from anterolateral corners so as to enclose a black non-iridescent spot on each side and to leave middle of scutum black widely - this iridecent pattern is somewhat variable with individuals: in 6 of 10 males examined, middle non-iridescent band is nearly paralled-sided on posterior $2 / 3$ and with rounded posterior end, and black spot on each side is large as shown in Fig. 16a; in 2 males, middle band is cuneiform and black spot on each side is of medium size as shown in Fig. 16b; in 1 male, though lateral black spots are subequal in size to those in the preceding 2 males, middle band is parallel-sided on anteior $2 / 3$ and narrowed posteriorly (Fig. 16c); in 1 male, lateral black spots are small, and additional anterior pair of small black spots are present, though somewhat faint, as shown in Fig. 16d; scutum uniformly covered with brown appressed hairs which appear bright in certain angles of light. Scutellum black, white pruinose, somewhat iridescent and with dark long hairs. Postscutellum black, white pruinose, sowewhat iridescent and bare. Pleural membrane and katepisternum bare. Legs. Coloured as in female except hind basitarsus (Fig. 13b) with more dark portion than in female. Fore basitarsus dilated, about $4.6 \times$ as long as its greatest width, and with conspicuous thick hair crest. Hind basitarsus (Fig. 13b) enlarged, $4.0 \times$ as long as its greatest width, and subequal in width to hind tibia. Calcipala and pedisulcus well developed. Wing. $\mathrm{C}$ with spinules and dark hairs. Sc bare. Basal section of $\mathrm{R}$ bare. $\mathrm{R}_{1}$ with a single row of spinules. Basal cell absent. Hair tuft on stem vein with dark hairs. Haltere white with petiole dark brown. Abdomen. Basal scale black with dark hair fringe. Dorsal surface of abdomen brownish black to black, and sparsely covered with dark hairs; tergites of segments 2, 4, 5, 6 and 7 each with a dorsolateral pair of iridescent, silvery white pruinose spots, which are broadly connected in the middle to each other in segment 2 but are narrowly connected in the remaining segments along anterior margin. Genitalia. Coxite (Fig. 26a) quadrate in ventral view, and a little longer than width. Style (Fig. 26e) elongate, much longer than coxite, nearly parallel-sided, about $3 \times$ as long as wide, somewhat flattened dorsoventrally, and with a single apical spine; style with basal protuberance produced dorsomedially, which is pointed apically (Fig. 26d). Body of ventral plate (Fig. 26a) nearly quadrate in ventral view, slightly shorter than width, and with hairy posteromedian process produced ventrally; posterolateral margins of posteromedian process not serrated, though slightly uneven (Fig. 26c); basal arms of moderate size, and somewhat divergent. Paramere (Fig. 26f) of moderate size, and with numerous small hooks. Median sclerite (Fig. 26g) broad, plate-like, and rounded distally. Pupa. Body length (excluding gill filaments) $3.2-3.4 \mathrm{~mm}$. Head and thorax. Integument brown, covered densely and elaborately with tubercles. Head with 1 facial pair and 2 frontal pairs of bifid or trifid trichomes. Thorax with 5 pairs of 3-6 branched trichomes. Gill (Fig. 31c) with 6 filaments arranged in pairs, upper pair of filaments shortly stalked but middle and lower pairs almost sessile; all filaments subequal in length and thickness, tapering toward tip, 
about $1 / 3 \times$ length of pupal body, with numerous sharp transverse ridges, and covered densely with minute tubercles. Abdomen. Tergum 1 pale ocherous, with 2 simple setae (1 long and the other short) on each side, and covered with no tubercles. Tergum 2 with 6 simple short setae in a row, of which 4 are stout and spinous on each side. Terga 3 and 4 each with 4 hooked spines along posterior margin on each side. Terga 5-7 lacking spine-combs. Tergum 8 with spine-combs composed of about 8 spines on each side. Terminal hook absent. Sternum 5 with 2 simple hooks submedially on each side. Sterna 6 and 7 each with 2 simple hooks, 1 submedially and 1 laterally on each side. Grapnel-like hooklets absent. Cocoon (Figs. 35a, b) shoe-shaped, tightly woven, and with narrow flange along ventrolateral margins; opening with thick lim.

Mature larva. Body length 5.0-6.0 mm. Body dark grey. Cephalic apotome (Fig. 42a) pale except portions along both sides and along posterior margin darkened; head spots markedly positive. Antenna composed of 4 segments, and longer than stem of cephalic fan; proportional length of segments 1-3 1.6:1.6:1.0. Cephalic fan with about 38 main rays. Mandible (Fig. 46) with normal arrangement of teeth, and without supernumerary mandibular serrations. Hypostomium (Fig. 42b) with a row of 9 apical teeth; median tooth slightly longer than corner teeth; corner teeth slightly longer than 3 intermediate teeth on each side, of which middle tooth smaller than its side teeth; lateral margin serrated; hypostomial setae 6-8 in number, lying divergent posteriorly from lateral margins. Postgenal cleft (Fig. 42b) deep, about $2.4 \times$ as long as postgenal bridge; both sides converging from base anteriorly. Thoracic and abdominal cuticle bare. Rectal gill lobes compound, each lobe with 6-9 finger-like secondary lobules. Anal sclerite of usual $\mathrm{X}$-form, with posterior arms about $1.4 \times$ as long as anterior ones; anterior arms broadly sclerotized. Ventral papillae absent. Posterior circlet with about 102 rows of about 16 hooks.

Type specimens: Holotype female (BMNH), slide-mounted; allotype male, slide-mounted; paratypes, 4 females, 9 males, 15 pupae, and 3 mature larvae, SULAWESI: Dumoga-Bone Reserve, tributary of Lake Mooat (near Kotinomobagu), D. M. Roberts, Sept. 1985.

Ecological notes: This species was only found in one small (1.5 m wide) slow-flowing stream near Lake Mooat. It was attached to trailing grass in association with $S$. $(G$.) rosemaryae. Distribution: Sulawesi.

Remarks: This new species may be assigned to the melanopus group, defined by Takaoka (1983) by having the unpatterned scutum, claws with small basal tooth, and paraproct with ventrointernal plate in the female, the 6 -filamented pupal gill and shoe-shaped cocoon. The female of this species is separated from all the known members of this group by the shape of the anterior gonapophyses and paraprocts (Fig. 22a). The characteristic, iridescent, pruinose scutal pattern of the male is very similar to that of $S$. (S.) laterale Edwards, 1933 from Sabah (Smart and Clifford, 1969), but the genitalia is quite different from each other. Particularly, the style of this species, which has the pointed basal protuberance (Fig. 26d), is distinct within the melanopus group. It is noteworthy that the similar basal protuberance in the male style is also possessed by the novolineatum group in the Oriental Region \{e.g. S. (S.) fenestratum Edwards, 1934 from Sumatra\}

The larva of this species-also differs from all the other related species by the shape of postgenal cleft (not widely rounded but gradually narrowed anteriorly) (Fig. 42b). 
Simulium (Simulium) tumpaense sp. nov.

Female. Body length 2.0-2.6 mm. Wing length 1.7-2.2 mm. Head. Narrower than width of thorax. Frons black, shiny, and covered with several dark hairs along lateral margins and near lower margin; frontal ratio 1.2:1.0:1.1; frons-head ratio 1.0:3.5. Clypeus black, shiny, whitish grey pruinose, and moderately covered with dark hairs. Antenna composed of $2+9$ segments, brown except scape, pedicel and base of 1st flagellar segment yellow. Maxillary palp with 5 segments, proportion of 3rd, 4th and 5th segments in length 1.0:1.2:2.5; 3rd segment (Fig. 6) normal in shape and size, and with small ellipsoidal sensory vesicle which is about $1.4 \times$ as long as wide. Maxilla serrated on both sides, with 12 outer teeth and 10 inner ones. Mandible serrulated on both sides, with 12 or 13 outer teeth and about 24 inner ones. Cibarium with a transverse row of about 10 small denticles and a cluster of numerous small denticles on median space, as shown in Fig. 8. Thorax. Scutum brownish black to black, shiny, faintly-whitish grey pruinose and somewhat iridescent, specially along lateral borders; scutum uniformly covered with dark appressed hairs. Scutellum brownish black, faintlywhitish grey pruinose, and with long and short upstanding dark hairs. Postscutellum brownish black to black, faintly-whitish grey pruinose, and bare. Pleural membrane and katepisternum bare. Legs. Fore coxa whitish yellow, and mid and hind coxae brownish black. All trochanters whitish yellow except mid one brown. Fore femur brown to dark brown, becoming darker towards distal end; mid and hind femora brownish black except extreme base of hind femur yellow. Fore tibia brownish black with median portion whitish yellow largely on outer surface; mid tibia brownish black except extreme base whitish yellow; hind tibia brownish black with more distinct whitish yellow portion at base than mid tibia, pale portion more extended on posterior surface than on anterior surface, thus its border with dark area oblique in lateral view; fore tibia with whitish sheen widely on outer surface, and mid and hind tibiae also with whitish sheen widely on posterior surface along basal $1 / 2$ of shaft. Fore tarsi black; basitarsus dilated, about $4.7 \times$ as long as its greatest width, and with medium dorsal hair crest. Mid tarsi brownish black to black except basal $2 / 3$ of basitarsus whitish yellow. Hind tarsi brownish black to black except basal $1 / 2$ of basitarsus (though base of basitarsus brownish black) and 2nd segment whitish yellow; basitarsus (Fig. 14a) narrow, nearly parallel-sided. Calcipala and pedisulcus well developed. Claw (Fig. 14c) simple, without tooth. Wing. C with spinules and hairs. Sc fully haired on undersurface. Basal section of $\mathrm{R}$ bare. $\mathrm{R}_{1}$ with spinules and hairs. $\mathrm{R}_{2}$ with hairs. Basal cell absent. Hair tuft on stem vein dark brown. Haltere white. Abdomen. Basal scale brownish black with pale hair fringe. Dorsal surface of abdominal segments brownish black to black, and sparsely covered with dark hairs; tergite of 2 nd segment with broad transverse whitish pruinosity; tergites of segments 5-8 shiny. Genitalia. Sternite 8 (Fig. 23a) of moderate size, much produced posteriorly, forming submedian triangular lobes, and with numerous stout hairs laterally and on these submedian lobes. Anterior gonapophysis (Figs. 23a, d) reduced, membraneous, and not well demarcated from posterior margin of produced submedian lobes of 8th sternite; gonapophysis-fused triangular lobes (Figs. 23a,d) transparent narrowly along posterior border and with small transparent tip bent ventrally on posteromedial corners. Genital fork (Fig. 23a) reversed-Y shaped, with stout, well-sclerotized stem; arms diverged laterally, and with heavily sclerotized distal ridge but having no marked projection. Paraproct (Figs. 23a, c) produced downwards, with brownish, elliptical, chitinized plate facing anteroventrally and somewhat medially, and moderately setose on lateral surface; this 
anteroventral plate furnished with about 40 hairs on its surface, most of which are pale and slender, but several hairs near posterior margin of plate are dark, somewhat stouter, and situated very close together, appearing, in lateral view, as dark bundled hairs; deep groove present laterally and posteriorly between chitinized plate and paraproct proper. Cercus (Fig. 23c) very short, rounded posteriorly, and moderately setose. Spermatheca (Fig. 23b) globose, and well sclerotized except small area of tubular base unsclerotized.

Male. Body length 2.3-3.0 mm. Wing length $1.6-1.9 \mathrm{~mm}$. Head. Width slightly wider than thorax. Holoptic; upper eye consisting of 14 or 15 horizontal rows and 13 or 14 vertical columns of large facets on each side. Face black, and silvery white pruinose. Clypeus black, silvery white pruinose and sparsely covered with dark hairs. Antenna composed of $2+9$ segments, yellowish brown to brown except scape, pedicel and base 1st flagellar segment yellow; 1st flagellar segment elongated, about $1.7 \times$ as long as 2nd flagellar segment. Maxillary palp with 5 segments, proportion of 3rd, 4th and 5th segments in length 1.0:1.4:2.7; 3rd segment not enlarged and with small sensory vesicle. Thorax. Scutum brownish black, with brilliant iridescent silvery pruinosity laterally and posteriorly and in 2 broad submedian bands extending from anterolateral corners so as to enclose a black non-iridescent spot on each side and to leave middle of scutum black widely, though lateral iridescent band usually disconnected to posterior iridescent pruinosity in front of wing base, as shown in Figs. 17a, b; scutum uniformly covered with brown appressed hairs which appear bright in certain angles of light. Scutellum brownish black, silvery white pruinose, somewhat iridescent and with long hairs. Postscutellum black, white pruinose, somewhat iridescent and bare. Pleural membrane and katepisternum bare. Legs. Coloured as in female. Fore basitarsus dilated, about $5.0 \times$ as long as its greatest width, and with medium thick hair crest. Hind basitarsus (Fig. 14b) only slightly enlarged, gradually widened to distal end (or widened towards basal $1 / 3$, then nearly parallel-sided up to distal end), about $3.8 \times$ as long as its greatest width, and about $3 / 4 \times$ as wide as greatest width of hind tibia. Calcipala and pedisulcus well developed. Wing. $\mathrm{C}$ with spinules and dark hairs. Sc bare. Basal section of $\mathrm{R}$ bare. $\mathrm{R}_{1}$ with a single row of spinules. Basal cell absent. Hair tuft on stem vein dark brown. Haltere white. Abdomen. Basal scale black with yellowish hair fringe. Dorsal surface of abdomen brownish black to black, and sparsely covered with dark hairs; tergites of segments 2, 4, 5, 6 and 7 each with a dorsolateral pair of silvery pruinose spots connected dorsally to each other along anterior margin; these pruinose spots somewhat iridescent in certain angles of light. Genitalia. Coxite (Fig. 27a) quadrate in ventral view, and a little longer than width. Style (Fig. 27e) elongate, much longer than coxite, nearly parallel-sided, about $2.6 \times$ as long as wide, somewhat flattened dorsoventrally, and with a single apical spine; style (Fig. 27d) with basal protuberance produced dorsomedially, which is serrated distally. Body of ventral plate quadrate in ventral view (Fig. 27a), slightly concave on posterior margin, and with low setose posteromedian process produced ventrally; posterolateral margins of posteromedian process (Figs. 27b, c) uneven, stair-stepped but not serrated; basal arms of moderate size, and widely divergent. Paramere of moderate size, and with numerous short hooks. Median sclerite broad, plate-like, and rounded distally.

Pupa. Body length (excluding gill filaments) 2.4-2.6 mm. Head and thorax. Integument yellowish brown, covered moderately with tubercles. Head with 1 facial pair and 2 frontal pairs of simple trichomes. Thorax with 6 pairs of simple trichomes. Gill (Fig. 32c) with 6 filaments arranged in pairs, very shortly stalked; all filaments subequal in length and thick- 
ness, tapering toward tip, about $2 / 5 \times$ length of pupal body, with numerous sharp transverse ridges, and covered densely with minute tubercles. Abdomen. Tergum 1 ocherous, with 2 simple setae ( 1 long and the other short) on each side, and covered sparsely with minute tubercles. Tergum 2 ocherous on basal $1 / 3$ to $1 / 2$, and with 6 simple short setae in a row, of which 3 are stout and spinous, on each side. Terga 3 and 4 each with 4 hooked spines along posterior margin on each side; tergum 3 ocherous on basal 1/3. Terga 5-7 lacking spinecombs. Tergum 8 with spine-combs in transverse row on each side. Terminal hook absent. Sternum 5 with 2 simple hooks submedially on each side. Sterna 6 and 7 each with 1 simple hook submedially on each side and lacking outer hook. Grapnel-like hooklets absent. Cocoon (Figs. 36a, b) shoe-shaped, closely and tightly woven, and with narrow flange along ventrolateral margins which is distinctly wider than that of $S$. $(S$.) dumogaense; opening with thick rim.

Mature larva. Body length $4.5-5.0 \mathrm{~mm}$. Body pale grey to dark greenish grey. Cephalic apotome (Fig. 43a) generally pale on anterior $1 / 2$ and dark on posterior $1 / 2$; head spots positive (though usually submerged in dark ground color) or negative. Antenna composed of 4 segments, and longer than stem of cephalic fan; proportional length of segments 1-3 1.6: 1.6:1.0. Cephalic fan with about 38 main rays. Mandible (Fig. 47) with normal arrangement of teeth, and without supernumerary mandibular serrations. Hypostomium (Fig. 43b) with a row of 9 apical teeth; median tooth as long as corner teeth, and longer than 3 intermediate teeth on each side, which are subequal in size to each other; lateral margin serrated; hypostomial setae 6 or 7 in number, lying divergent posteriorly from lateral margins. Postgenal cleft (Fig. 43b) deep, rounded, constricted near base, and about $7.5 \times$ as long as postgenal bridge. Thoracic and abdominal cuticle bare. Rectal gill lobes compound, with 6-9 finger-like secondary lobules. Anal sclerite of usual X-from, with posterior arms about $1.8 \times$ as long as anterior ones; anterior arms broadly sclerotized. Ventral papillae absent. Posterior circlet with about 88 rows of about 13 hooks.

Type specimens: Holotype female (BMNH), slide-mounted; allotype male, slide-mounted; paratypes, 25 females, 24 males, 20 pupae, and 44 mature larvae, in alcohol, SULAWESI: Dumoga-Bone Reserve, R. Tumpah, D. M. Roberts, Sept. 1985; 2 females, 2 males, pinned, 7 pupae, 4 pupal skins, 1 cocoon, 4 mature larvae and 11 immature larvae in alcohol (BMNH), Dumoga-Bone, Dumoga Valley, irrigation channel to R. Toraut, near Project Wallace Camp area, G. B. White, Dec. 1985.

Ecological notes: This was the dominant species in the large rivers Toraut and Tumpah (20$30 \mathrm{~m}$ wide) and was most abundant in the highest velocities (Fig. 48a). Large numbers were also present in small feeder canals ( $1 \mathrm{~m}$ wide) of the Toraut irrigation system in the Dumoga Valley, where velocities over $2 \mathrm{~m} / \mathrm{sec}$. were recorded. A few were found in rapids in small tributaries of the R. Toraut (Fig. 48b). In the R. Toraut and R. Tumpah, larvae were usually attached to dead leaves, with a few on rock; in the irrigation canals, they were attached to trailing vegetation. They were found at altitudes of $200-500 \mathrm{~m}$ in the R. Tumpah, and were also present in streams flowing into Lake Mooat $(1,100 \mathrm{~m})$.

Distribution: Sulawesi.

Remarks: This new species also belongs to the melanopus group, and the pupa and larva have a close similarity to those of the other members of the group. The female of this species lacks a claw tooth, as does the female of $S$. (S.) discrepans Delfinado, 1969 from the Philippines (Takaoka, 1983). However, there is a difference in the shape of the anterior gonapophyses 
and paraprocts between the two species. This species possesses a characteristic, iridescent, pruinose pattern on the male scutum (Fig. 17a), which is, however, different from that of $S$. $(S$.) dumogaense and $S$. (S.) laterale. The male genitalia resembles that of $S$. (S.) dumogaense except the style with a serrated basal protuberance (Fig. 27d). By having this form of the style, $S$. ( $S$.) tumpaense is easily separated from all the other members of the melanopus group.

\section{ACKNOWLEDGEMENTS}

This paper is based on materials collected while D. M. Roberts was a participant in "Project Wallace", sponsored by the Royal Entomological Society of London and the Indonesian Institute of Sciences, to which our sincere appreciation is expressed.

We are grateful to Dr. R.W. Crosskey, Department of Entomology, British Museum (Natural Histroy), London, U.K., who kindly loaned the other simuliid specimens collected by Drs. R.H.L. Disney and G.B. White, and provided valuable suggestions for this study.

Thanks are also due to Dr. D.M. Davies, Professor Emeritus, McMaster University, Ontario, Canada, for his encouragement and valuable comments.

\section{REFERENCES}

1) Brunetti, E. (1911): New Oriental Nematocera, Rec. Indian Mus., 4, 283-288

2 ) Crosskey, R.W. (1969): A re-classification of the Simuliidae (Diptera) of Africa and its islands, Bull. Br. Mus. Nat. Hist. (Entomol.), Suppl. 14, p.195

3 ) Crosskey, R.W. (1981): Simuliid Taxonomy - The contemporary scene, p. 3-18, In: Laird, M. (ed.) Blackflies: The future for biological methods in integrated control, Academic Press p.399

4 ) Datta, M. (1973): New species of black flies (Diptera: Simuliidae) of the subgenera Eusimulium Roubaud and Gomphostilbia Enderlein from Darjeeling area, India, Orient. Insects., 7, 363-402

5 ) Davies, D.M. and Györkös, H. (1987): The Simuliidae (Diptera) of Sri Lanka. Descriptions of species in the subgenera Eusimulium and Gomphostilbia of the genus Simulium, Can. J. Zool., 65, 1483-1502

6) Edwards, F.W. (1934): Deutsche Limnologische Sunda-Expedition. The Simuliidae (Diptera) of Java and Sumatra, Arch. F. Hydrobiol., Suppl., 13, 92-138

7 ) Puri, I.M. (1933): Studies on Indian Simuliidae Part VIII. Description of larvae, pupae, males and females of $S$. aureohirtum Brunetti and $S$. aureum Fries, Indian J. Med. Res., 21, 1-9

8 ) Roberts, D.M. and Okafor, B.C. (1987): Microdistribution of immature blackflies resulting from water velocity and turbulence preferences, Med. Vet. Ent., 1, 169-175

9 ) Smart, J. and Clifford, E.A. (1969): Simuliidae (Diptera) of Sabah (British North Borneo), Zool. J. Linn. Soc., 48, 9-47

10) Takaoka, H. (1973): Descriptions of 2 new species of blackflies, Simulium (Gomphostilbia) tokarense and $S$. (Eusimulium) morisonoi (Diptera: Simuliidae), from the Tokara Islands, Japan, Jpn. J. Sanit. Zool., 23, 201-207

11) Takaoka, H. (1976): Studies on black flies of the Nansei Islands, Japan (Simuliidae: Diptera). II. On six species of the subgenera, Gomphostilbia Enderlein, Morops Enderlein, Odagmia Enderlein and Gnus Rubzov with the description of Simulium (Gomphostilbia) okinawense sp. nov., Jpn. J. Sanit. Zool., 27, 385-398 
12) Takaoka, H. (1979): The black flies of Taiwan (Diptera: Simuliidae), Pac. Insects, 20, 365403

13) Takaoka, H. (1983): The blackflies (Diptera: Simuliidae) of the Philippines, Japanese Society for the Promotion of Science, Tokyo, p.210

14) Takaoka, H. and Noda, S. (1979): Autogeny of the black fly Simulium (Eusimulium) aureohirtum (Diptera: Simuliidae), J. Med. Entomol., 15, 183-184

15) Takaoka, H. and Suzuki, H. (1984): The blackflies (Diptera: Simuliidae) from Thailand, Jpn. J. Sanit. Zool., 35, 7-45.

\author{
インドネシア，スラウェシで採集されたブユについて \\ 高岡 宏行 ${ }^{1}$ D. M. Roberts ${ }^{2}$
}

インドネシアのスラウェシ島北部の, Dumoga-Bone国立公園内で採集されたブユの標本を分 類学的に検討した。その結果, 既知種 1 種, 新種 6 種を含む 9 種が分布していることが分かった。 これらはブユ属 (Simulium)の 4 亜属 (Nevermannia, Morops, Gomphostilbia, Simulium s. str.) に分類された。これらブユ種の成虫, 蛹, 幼虫期の検索表を作り, 新種の記載を行った。また幼 虫の生息状況に関しても簡単に触れた。

1 大分医科大学医動物学教室

2 Department of Zoology, University of Jos, Nigeria 